\title{
Amphibolites in the rare metal- and tin-bearing Bastar-Malkangiri pegmatite belt in Chhattisgarh and Odisha, India
}

\author{
P V RAmesh BaBU ${ }^{1,2}$ and R Dhana RAJU ${ }^{1,3, *}$ \\ ${ }^{1}$ Atomic Minerals Directorate for Exploration and Research, DAE, Hyderabad 500 016, India. \\ ${ }^{2}$ Present address: Flat No. 101, Priya Arcade, Srinagar Colony, Hyderbad 500 073, India. \\ ${ }^{3}$ Present address: 1-10-284/1, Begumpet, Brahmanwadi Lane no. 5, Hyderbad 500 016, India. \\ *Corresponding author.e-mail: dhanaraju.reddi@gmail.com
}

MS received 26 February 2018; revised 27 April 2018; accepted 30 April 2018;

published online 1 February 2019

Amphibolites and Abukuma-type low-grade and low-pressure meta-sedimentary rocks (MSR) host mineralised rare metal ( $\mathrm{Nb}-\mathrm{Ta}, \mathrm{Be}$ and $\mathrm{Li}$ )- and Sn-bearing granite pegmatites and their parental, fertile S-type granites in the Bastar-Malkangiri Pegmatite Belt (BMPB) in the SE part of the Bastar craton in parts of Chhattisgarh and Odisha, India. Amphibolites, based on their field relationship (as sills in MSR), mineral assemblage and textural features, are broadly classified into three types: (i) tremolite-, (ii) hornblende-actinolite-, and (iii) hornblende-bearing amphibolites. Petrochemically, amphibolite types (i-iii) show a regular decrease in their $\mathrm{Mg}$ content and related trace elements such as $\mathrm{Cr}(81-1731 \mathrm{ppm})$, $\mathrm{Ni}(135-379 \mathrm{ppm})$ and Co (23-68 ppm) and, hence, are designated, respectively, as high-, intermediateand low-Mg amphibolites. All the three types show slight enrichment in $\mathrm{Si}, \mathrm{Fe}$ and $\mathrm{P}$, reflected in their normative quartz, hypersthene and lesser diopside, magnetite, ilmenite and apatite, but no olivine. They are relatively enriched in incompatible elements such as Rb (16-526 ppm), Ba (15-538 ppm), Zr (56-147 ppm) and $\mathrm{Nb}(3-44 \mathrm{ppm})$, with relatively a higher concentration of these elements in those near to the contacts with pegmatites, thereby demonstrating some influence of the pegmatites on the chemistry of the host amphibolites. In spite of these, the three types of amphibolites show regular differentiation trends, reflected by their systematic decrease of $\mathrm{Ni}, \mathrm{Cr}$ and $\mathrm{Co}$ with a decrease of $\mathrm{Mg}$, and also show Fe-enrichment in their alkalies $\left(\mathrm{Na}_{2} \mathrm{O}+\mathrm{K}_{2} \mathrm{O}\right)-\left(\mathrm{FeO}+\mathrm{Fe}_{2} \mathrm{O}_{3}\right)-\mathrm{MgO}(\mathrm{AFM})$ plot. The field, petrography and major-minor trace elements petrochemistry, including rare earth elements with slight negative to no Eu-anomaly, and their chemical patterns cumulatively point out that these amphibolites are ortho-type and sub-alkaline in nature, with quartz tholeiitic magmatic affinity, and the formation due to more of fractional crystallisation and less of 5-25\% partial melting of an enriched primordial mantle magma (enriched mid-oceanic ridge basalt - E-MORB), emplaced at a deduced shallow depth of 10-25 km, with the main controlling phases being olivine, plagioclase, clinopyroxene and apatite.

Keywords. Amphibolites; Bastar-Malkangiri Pegmatite Belt; Odisha-Chhattisgarh; India.

\section{Introduction}

The Bastar-Malkangiri Pegmatite Belt (BMPB), in parts of the Chhattisgarh and Odisha states of
India, is well known for primary and secondary commercial deposits of tin and rare metals (RMs), viz., lithium, beryllium, niobium and tantalum, manifested as cassiterite, lepidolite, amblygonite, 
beryl and columbite-tantalite, with no commercial mica (Deshpande 1976; Ramaswamy et al. 1976; Murthy et al. 1979; Ramachar et al. 1979; Lamba and Khanna 1981; Ramesh Babu and Ramachar 1983; Lamba and Agarkar 1988; Acharya et al. 1989; Ramesh Babu 1993, 1999). Earlier, Crookshank (1963) and Bhola and Bhatnagar (1969) reported the occurrence of lepidolite and beryl from the pegmatites around Mundval. BMPB extends over $80 \mathrm{~km}$ in an NW-SE direction from Dantewada in the Bastar district of Chhattisgarh on the northwest to Salimi in the Malkangiri district of Odisha on the southeast and passes through the villages of Metapal, Katekalyan, Tongpal, Govindpal, Mundval, Mundaguda and Dammoguda (Ramesh Babu 1990). In BMPB, the pegmatites are intimately associated with granites that, in turn, were emplaced in the Precambrian Bengpal Group of rocks, comprising meta-sedimentary rocks and amphibolites. We present here the geological setting, structure, petrography and petrochemistry of the amphibolites in the study area, and discuss their implication on the petrogenetic aspects of these amphibolites, besides probing the bearing of these amphibolites on the pegmatitic RM mineralisation in the area.

\section{Geological setting}

The BMPB, in parts of Chhattisgarh and Odisha, forms the SE part of the Bastar craton in central India (figure 1). It extends over $80 \mathrm{~km}$ in length, with 15-20 km width, in a general NW-SE direction, starting from Dantewada in the Bastar district (Chhattisgarh) in NW to Salimi in the Malkangiri district (Odisha) in SE. It is bound by the Indravati basin in the north, Sukma basin in the south, Eastern Ghat complex in the east and Bailadila Iron Ore Group in the west. In the area under study, the oldest rocks exposed are the Archaean meta-sedimentary and metabasic rocks (amphibolites) of the Bengpal Group, with a regional metamorphic event around $2530 \pm$ $89 \mathrm{Ma}$, defined by their migmatitic leucosome (Bandyopadhyay et al. 1990; Ramakrishnan 1990). Palaeoproterozoic granitoids, known as Paliam and Darba granites in the SE part of BMPB (2308 \pm $48 \mathrm{Ma}$, Ramesh Babu et al. 1993), pegmatites, quartz veins and dolerites emplaced/intruded into the Bengpal Group of rocks, and the entire sequence iss unconformably overlain by the Neoproterozoic Indravati Group of sediments. The meta-sedimentary rocks of the Bengpal Group are mainly argillaceous and arenaceous in bulk composition and comprise andalusite schist (with cordierite, at places), quartz-mica schist, sericite quartzite and quartzite. Thin bands and lenses of banded magnetite quartzite are common in the NW part of BMPB. Amphibolites occur mainly as sills in the meta-sedimentary rocks. In the NW part of the belt, these occur at the contact of meta-sedimentary rocks and granites. Paliam and Darba granites in the SE part as well as the granites around Pakanar and Metapal in the NW part of BMPB were emplaced into the Bengpal Group of rocks, with their contacts being fairly sharp at north of Hirapa Dongri and south of Arval Dongri (Ramesh Babu and Dhana Raju 2016). At places, the thin zone of granitised schist occurs in the contacts. The andalusite schist at the contact of granites is undulated and transformed into the coarse-grained muscovite schist. Granites, at the contact with the meta-sedimentary rocks, show flow banding/foliation, almost parallel to the margins and contain xenoliths of the latter. In the marginal parts of the Paliam granite, greisenisation (cf. Lamba and Agarkar 1988), marked by muscovite-rich (up to 13.5 vol\%) zones and occurrence of fluorite and topaz, is recorded. Pegmatites occur intruding most of the earlier rock formations (Bengpal Group and granites) and show varied internal zoning, mineralogy and Sn-RM-mineralisation, based on which they are classified into five types, viz., type I: barren, simple, unzoned biotite or muscovite-microcline pegmatites; type II: partly differentiated muscovitemicrocline pegmatites with beryl; type III: fully differentiated muscovite-microcline pegmatites with beryl, columbite-tantalite \pm cassiterite; type IV: replaced lepidolite-albite-muscovite pegmatites with amblygonite, cassiterite, beryl \pm columbitetantalite; and type $\mathrm{V}$ : replaced muscovite-albite pegmatites with cassiterite and beryl (Ramesh Babu 1993, 1999).

Amphibolites occupy a large part of the study area. They are dark coloured, hard, massive and, being resistant to weathering, as compared to surrounding schists, stand out prominently and form hill ranges. Large bodies of these are exposed to the north of Churwada trending E-W, the south of Mundval and Tongpal trending E-W to NW-SE, and around Marjun. Comparatively thinner bands are also seen at Rangawada, Peramarasu, Mohpodoro and west of Kukri metta. Amphibolites have intruded all the 


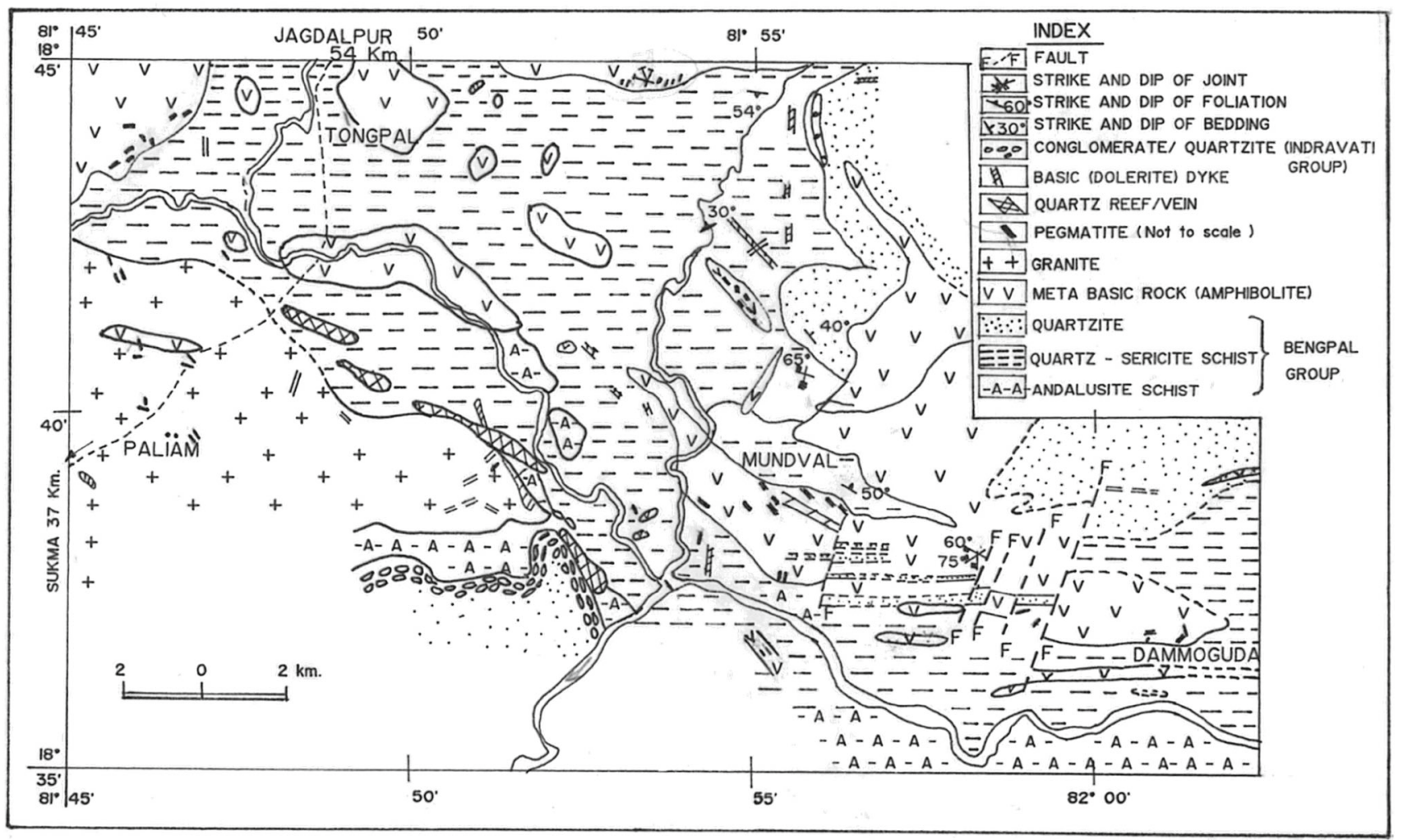

Figure 1. Generalised geological map of southern Bastar craton, showing BMPB and the Garda-Toyar area (Geology, after Ramakrishnan 1990).

meta-sedimentary rocks of the Bengpal Group, mostly as sills with sharp contacts, although the cross-cutting relationship is noticed, at places. They are of two distinct types: (i) large massive, thicker and medium-grained bodies such as those north of Churwada, south of Mundval and around Marjun, which do not show much contact effects and into which many pegmatites, including the mineralised tin- and RM-bearing ones, are emplaced; and (ii) relatively thinner and small bodies at Rangawada, Peramarasu, Mohpodoro and west of Kukri metta, which are devoid of any major pegmatite veins, including mineralised ones. Based on the specific phase of amphiboles, these amphibolites are classified into three types, viz., tremolite-, hornblende-actinolite- and hornblende-bearing amphibolites, corresponding, respectively, to high$\mathrm{Mg}(9-16 \% \mathrm{MgO})$, intermediate- $\mathrm{Mg}(7-10 \% \mathrm{MgO})$ and low- $\mathrm{Mg}(4-7 \% \mathrm{MgO})$ amphibolites. They are mostly massive, with the first two types generally occurring together and the tremolite-bearing ones at lower levels compared to the other two, whereas hornblende-bearing amphibolites are of smaller dimensions and spatially separated from the first two types.

\section{Structural aspects}

A perusal of the geological map of southern Bastar and Jeypore by Crookshank (1963) suggests a closed regional structure west of Kukanar, extending in NW-SE direction between Gariapal and Muripal villages. From the disposition of rock formations, it is inferred that the major structure is a doubly plunging, overturned anticlinorium with the area having been subjected to a minimum of the following two cycles of folding: (i) due to compressional forces roughly from NNE-SSW $\left(F_{1}\right)$, which have thrown the formations into overturned folds with E-W to WNW-ESE trends and NNE axial plane dipping; and (ii) second set of compressional forces from WNW-ESE have refolded the axes of the first-order folds, with trend of crossfold $\left(F_{2}\right)$ axes being NNE-SSW, sub-parallel to the $F_{1}$ compressional forces. The meta-sedimentary rocks in the study area show ENE-WSW to E-W and NW-SE regional trend with northerly dips. The longer axis of the amphibolites is aligned more or less parallel to the regional trend of the meta-sedimentary rocks. However, in the NW portion around Marjun, the discordant relationship 
is noticed. Abundant emplacement of pegmatites had taken place along the shears. The amphibolites were subjected to profuse emplacement of pegmatites, especially near to their contact with meta-sedimentary rocks. The area was subjected to intense faulting, especially in the SE part. The major trend is NNE-SSW and sub-parallel to the major lineament along which the Sabari river flows. The straight course of the Bhimsen river and the steep scarps of the Kukri metta hill are also attributable to a major fault. The faulting appears to be post-pegmatitic, as has been observed north of Gurupada village, where a pegmatite of $\sim 30-50 \mathrm{~cm}$ thickness was dislocated by five fault planes. Along the faults to the NE of the centre, the movement is sinistral, while those to SW of the centre have dextral movement. The lineament and drainage analysis, based on LANDSAT imagery and aerial photographs, indicates five major trends, viz., NW-SE, WNW-ESE, NNWSSE, ENE-WSW and NNE-SSW, which appear to represent the deep-seated fractures in the crust (Chawla unpublished report 1988).

\section{Methods of study}

The methods of the study adopted are those of petrography and petrochemistry.

\subsection{Petrography}

This includes thin-section study in the transmitted light and a few sections in reflected light. Microscopic study for different aspects, such as rock nomenclature, texture, mineralogical alterations, determination of An-content of plagioclase by extinction angle method and mode, was carried out on a Leitz Orthoplan microscope having a facility for simultaneous study in both transmitted and reflected light. During the mineragraphic study, quantitative determinations of per cent reflectivity $(R)$ at $546 \mathrm{~nm}$ and micro-hardness (Vicker's hardness number, VHN) of ore minerals were carried out using Leitz equipment. The modal analysis of 20 representative samples was done, after staining for feldspars, by point count method (with about 3000 counts for each sample) using a Swift automatic point counter. Photomicrography was done by the Leitz Variomat automatic photographic accessory, fitted to the above microscope.

\subsection{Petrochemistry}

The major and minor element analysis of rocks, in terms of oxides, swas carried out using the rapid wet chemical methods, essentially after Shapiro and Brannock (1955). Details of various techniques used in this, involving sample and solution (I and II) preparations and instruments used such as (i) atomic absorption spectrophotometry for Al, $\mathrm{Fe}^{\mathrm{t}}, \mathrm{Mg}, \mathrm{Ca}$ and $\mathrm{Mn}$; (ii) spectrophotometry for $\mathrm{Si}$, Ti and P; (c) flame photometry for alkalies; (d) titrimetry for $\mathrm{Fe}^{2+}$; and (e) gravimetry for $\mathrm{H}_{2} \mathrm{O}$, were given elsewhere (Satyanarayana 1986) and the same were adopted in this study. International Rock Standards (IRS) - AGV-1 and BCR-1 - were used as a check on the analysis. The per cent errors involved with reference to the value of these standards for different analysed radicals are as follows: $\mathrm{SiO}_{2}: \pm 0.8, \mathrm{TiO}_{2}: \pm 3, \mathrm{Al}_{2} \mathrm{O}_{3}: \pm 0.4$, $\mathrm{Fe}_{2} \mathrm{O}_{3}: \pm 1, \mathrm{FeO}: \pm 2.5, \mathrm{MnO}: \pm 2, \mathrm{MgO}: \pm 1.3$, $\mathrm{CaO}: \pm 0.6, \mathrm{Na}_{2} \mathrm{O}$ and $\mathrm{K}_{2} \mathrm{O}: \pm 1.6$ and $\mathrm{P}_{2} \mathrm{O}_{5}: \pm 6$. Trace elements - Rb, Sr, Ba, Pb, Y, Zr, Ni, Co, $\mathrm{Cr}, \mathrm{V}$ and $\mathrm{Zn}$ - in rock samples were determined by WDXRFS (Wavelength Dispersive X-ray Fluorescence), following the methods of determination given by Viswanathan (1989), using the K- $\alpha$ spectra of the above trace elements, except $\mathrm{Pb}$ for which L-beta spectra were used, with rhodium X-ray tube as the excitation source. The resultant secondary $\mathrm{X}$-radiation was collimated $(150 \mu \mathrm{m})$ and dispersed, using a LiF 220 analysing crystal. The intensity of each radiation was measured with a scintillation counter. The data were calibrated using different appropriate IRS. The resultant regression equations of the form $y=a+b x$ (where $y$ is the concentration of the element, $a$ is the intercept, $b$ is the slope and $x$ is counts/second of the characteristic radiation of the element) were used to compute the element concentration in the samples for different determined values of ' $x$ '. For each sample, at least three determinations were made and their arithmetic mean of the concentration of element was finally taken. For the elements analysed, a precision and accuracy of $\pm 10-20 \%$ was obtained at their lowest level of concentration in the sample, with respect to IRS. Rare earth elements (REE: La, Ce, Sm, Eu, Tb, Yb and $\mathrm{Lu}$ ) were determined by Instrumental Neutron Activation Analysis (INAA), following the methods of Reddy et al. (1975) and Gurna et al. (1988), using APSARA reactor, 45 cc Ge (Li) detector, 1024 channel analyser, $5 \mathrm{~h}$ time and $2.3 \mathrm{keV}$ at 1332 $\mathrm{keV}$ system resolution. The statistical error at $1 \sigma$ 
level for the counts collected for the peak of interest of $\mathrm{La}, \mathrm{Ce}, \mathrm{Sm}, \mathrm{Yb}$ and $\mathrm{Lu}$ is $< \pm 10 \%$ and for $\mathrm{Eu}$ and $\mathrm{Tb}$ is $< \pm 15 \%$.

\section{Petrography}

Amphibolites are medium grained and contain essentially one or two amphiboles (tremolite, actinolite and hornblende) and plagioclase as major minerals, with minor to accessory quartz, chlorite, zoisite, epidote, sphene, apatite, rutile, opaque ore minerals (ilmenite, magnetite and sulphides) and rarely microcline. Texturally, these rocks are massive with relict ophitic to sub-ophitic texture, defined by large laths of hornblende/actinolitetremolite (after pyroxene) enclosing highly sericitised, idioblastic plagioclase laths, preserved in some samples. Occasionally, they are feebly foliated due to the rough orientation of chlorite at south of Mundval. Myremekitic and granophyric textures were noticed in some samples. Hornblende is mostly prismatic in habit, often clustering and with rugged terminations. Basal sections are euhedral prismatic with four or eight sides, and show perfect two sets of cleavage at an angle of $56^{\circ}$. It is in different shades of green and bluish green colour, and is pleochroic. Twinning is very common. Extinction angle $(Z \wedge C)$ varies from $22^{\circ}$ to $24^{\circ}$ and rarely up to $31^{\circ}$. It alters to chlorite and zoisite. Tremolite is colourless and is either long, tabular prismatic crystal or columnar to aggregate fibrous in form. Many grains show simple twinning. Extinction angle varies from $18^{\circ}$ to $21^{\circ}$, indicating that tremolite is Mg-rich. Actinolite is pale green, feebly pleochroic and similar to tremolite in habit, with extinction angle ranging from $10^{\circ}$ to $15^{\circ}$. At places, two generations of amphiboles are seen - the earlier formed one as tabular prisms of tremolite/actinolite, enclosed by xenoblastic prisms of common hornblende. Plagioclase is mostly subhedral to euhedral in habit and is twinned after complex laws such as combined carlsbad and albite, and albite and pericline laws. Usually, it is much altered to sericite or fine aggregates of saussurite, with some grains showing less alteration. Although the alteration is intense, the majority of the grains retain twinning. Occasionally, two modes of plagioclase are seen, with larger xenoblastic grains completely sericitised and smaller relatively fresh grains showing lamellar twinning. Anorthite content (determined after Michel Levy's method) varies from 34\% to
$42 \% \pm 3 \%$. Quartz occurs in minor amount as (i) medium- to coarse-grained xenoblasts, occupying the interstices and (ii) cuniform type in myrmekitic and granophyric intergrowths with plagioclase; it normally shows wavy extinction. Chlorite is an important accessory mineral, mostly occurring as an alteration product of the amphiboles. In tremolite-bearing rocks, it is Mg-rich showing anomalous brown interference colours and lengthfast character, whereas in hornblende-rich rocks, it is Fe-rich with anomalous violet or blue interference colours and length-slow character. Usually, aggregates of chlorite are associated with sphene and opaque minerals. Zoisite occurs as an alteration product of amphiboles, while epidote occurs as an alteration product of both amphiboles and plagioclase. Sphene occurs in almost all the samples as wedge-shaped crystal and in clusters of drop-like granules. It occurs around ilmenite with nearby alteration of amphibole to chlorite, indicating its formation due to released $\mathrm{Ti}$ and $\mathrm{Ca}$ from ilmenite and amphiboles, respectively. Apatite occurs as columnar and clusters of radiating needles. Fresh microcline crystals, showing typical cross-hatched twinning, are seen rarely in smaller basic intrusive bodies containing relatively higher plagioclase content. Ilmenite occurs as tabular and prismatic crystal, replaced by anatase along margins. Rutile is deep brown in colour, with red internal reflections and occurs as prisms, either around grain margins or as fracture filling of amphibole grains. Minor irregular-shaped pyrrhotite, showing strong bireflectance and anisotropism, occurs in some samples. Traces of ultrafine grains of other sulphides, with chalcopyrite replaced by bornite, are seen in a few sections. Based on the presence of a type of major amphibole, the amphibolites in the study area are broadly classified into three types, viz., (i) tremolite-, (ii) hornblende-actinolite- and (iii) hornblende-bearing amphibolites. A few textural features of the amphibolites are given in plate 1 .

Modal composition (in vol.\%) of these amphibolites is given in table 1. An examination of the modal composition reveals that the amphibolites intrusive in different parts of the area show variation both in type and content of amphiboles as well as plagioclase. Thus, those of Govindpal, Beikupli and Chintalnar (sl. nos. 1-6 in table 1) are light coloured comprising mainly tremolite, whereas those north of Churwada, Kudripal and Mindaguda (sl. nos. 7-14) comprise mainly hornblende with minor actinolite. It may be noted that the samples of massive amphibolites south of 

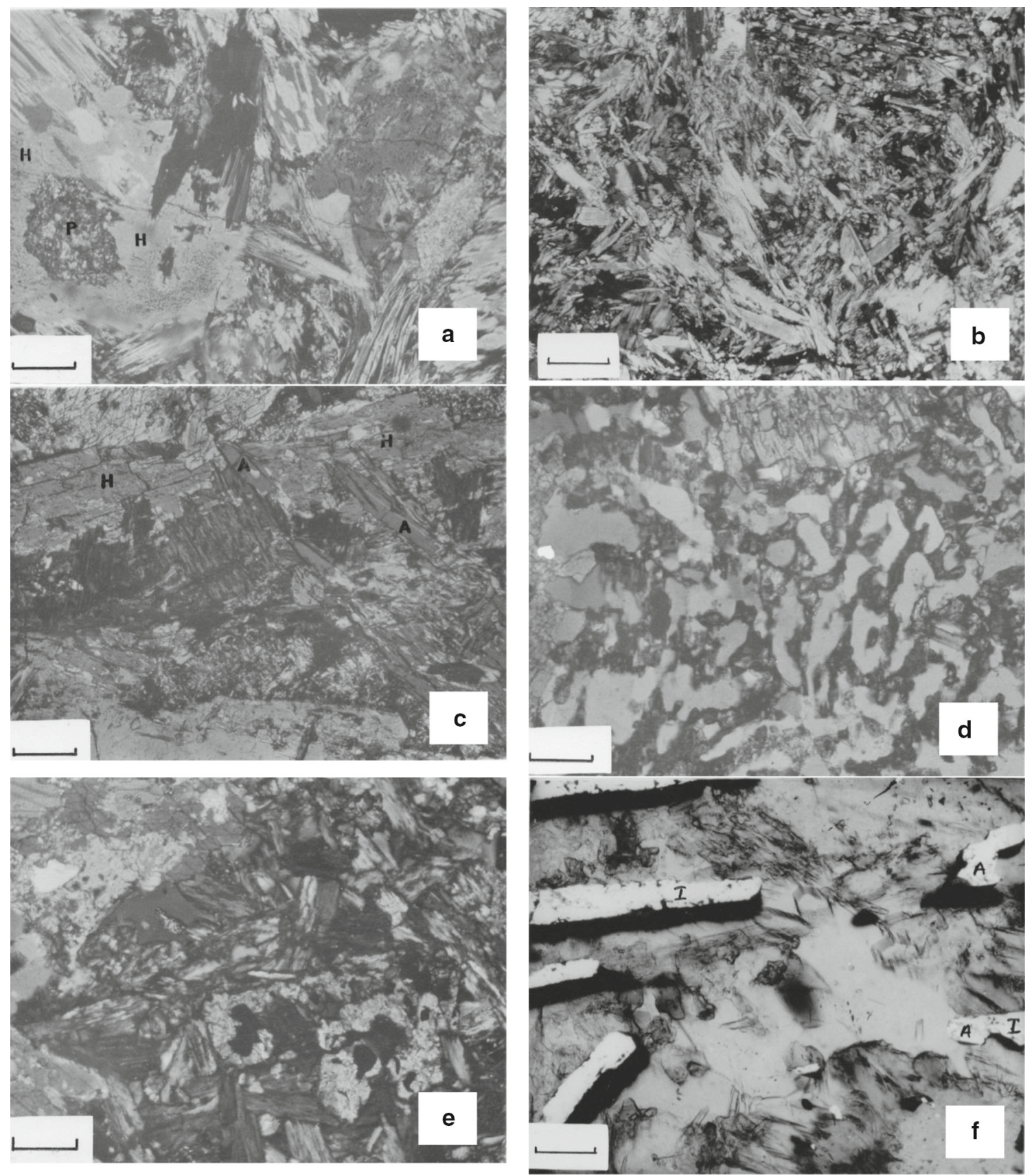

Plate 1. (a) Amphibolite showing relict ophitic texture, with hornblende $(\mathrm{H})$ enclosing highly sericitised plagioclase. PPL, + N, Bar: $0.26 \mathrm{~mm}$. (b) Amphibolite with typical fibrous and columnar aggregate of tremolite. PPL, +N, Bar: 0.29 mm. (c) Two generations of amphiboles, the first formed as columnar actinolite (A), enclosed in xenoblastic prisms of chloritised hornblende $(\mathrm{H})$. PPL, +N, Bar: $0.17 \mathrm{~mm}$. (d) Intergrowth of cuniform quartz and saussuritised plagioclase. PPL, +N, Bar: $0.16 \mathrm{~mm}$. (e) Sphene occurring around opaque grains (ilmenite), with nearby alteration of amphibole to chlorite. PPL, $+\mathrm{N}$, Bar: $0.19 \mathrm{~mm}$. (f) Ilmenite (I), occurring as tabular and prismatic crystals, replaced by anatase (A). RL, oil; 1 N, Bar: 0.09 $\mathrm{mm}$.

Mundval (sl. nos. 3 and 8) contain both hornblende and tremolite, indicating probably a complex or multiple intrusions. Likewise, the amphibolites of Marjun and Churwada are also considered to be multiple intrusive bodies. In contrast to the presence of both hornblende- and tremolite-rich larger bodies of amphibolites, the smaller bodies of Permarasu, Rangawada and Kukri metta comprise chiefly common hornblende. Anorthite content of plagioclase in larger bodies of amphibolites varies from $40 \%$ to $42 \%$, whereas in the small bodies of amphibolites it varies from $34 \%$ to $36 \%$. The lower 
Table 1. Modal analysis (in vol.\%) of the amphibolites from BMPB.

\begin{tabular}{|c|c|c|c|c|c|c|c|c|c|c|}
\hline Sl. no. & Tremol. & Hornbl. & Actin. & Plag. & Zoisite & Chlorite & Quartz & Sphene & Apatite & Opaques \\
\hline 1. B-7 & 63.0 & - & - & 33.5 & - & - & 2.5 & 0.5 & - & 0.5 \\
\hline 2. B-27 & 62.4 & - & - & 20.0 & 14.0 & 1.0 & 2.5 & - & - & 0.1 \\
\hline 3. B-24 & 60.0 & - & - & 25.0 & 4.0 & 3.0 & 6.0 & - & 0.5 & 1.5 \\
\hline 4. B-34 & 53.5 & - & - & 31.5 & 13.0 & - & 1.0 & - & - & 1.0 \\
\hline 5. B-39 & 62.7 & - & - & 36.0 & - & - & 0.4 & 0.1 & 0.1 & 0.7 \\
\hline 6. B-35 & 61.0 & - & - & 20.0 & 15.5 & 0.5 & 2.0 & 0.7 & 0.2 & 0.1 \\
\hline 7. B-22 & - & 47.3 & 5.8 & 31.3 & 1.8 & 0.3 & 11.8 & - & 0.5 & 1.2 \\
\hline 8. B-12 & - & 49.0 & 15.3 & 33.0 & - & - & 2.4 & - & - & 0.3 \\
\hline 9. B-51 & - & 55.0 & 2.2 & 33.8 & - & 4.5 & 3.0 & 1.0 & 0.3 & 0.2 \\
\hline 10. B-18 & - & 63.2 & 0.1 & 24.8 & 1.4 & - & 8.6 & 0.9 & - & 1.0 \\
\hline 11. B-20 & - & 46.2 & 0.2 & 25.4 & 0.1 & 10.5 & 15.4 & 1.7 & 0.1 & 0.4 \\
\hline 12. B-11 & - & 48.0 & 4.5 & 42.0 & 1.5 & - & 2.0 & 1.5 & 0.5 & - \\
\hline 13. B-10 & - & 65.9 & 0.6 & 21.7 & - & 1.7 & 7.8 & 1.8 & 0.1 & 0.4 \\
\hline 14. B-52 & - & 45.0 & 2.7 & 39.0 & 1.0 & - & 11.9 & 0.1 & - & 0.3 \\
\hline 15. B-19 & 0.8 & 41.4 & - & 42.4 & 4.7 & - & 10.0 & - & - & 0.7 \\
\hline 16. B-21 & 0.2 & 37.6 & - & 51.7 & 1.0 & 0.4 & 8.6 & 0.5 & - & - \\
\hline 17. B-6 & - & 50.0 & - & 43.5 & 2.0 & - & 2.0 & 2.0 & 0.5 & - \\
\hline 18. B-3 & - & 45.0 & - & 43.0 & 4.5 & s3.5 & 1.0 & 2.5 & 0.4 & 0.6 \\
\hline 19. B-46 & - & 40.0 & - & 39.8 & - & 5.8 & 13.4 & 1.0 & - & - \\
\hline 20. B-32 & $\operatorname{Tr} / \operatorname{act} 0.2$ & 40.2 & - & 41.2 & 0.7 & - & 13.8 & 3.5 & 0.4 & - \\
\hline
\end{tabular}

N.B.: Sl. nos. 1-6: tremolite-bearing amphibolites; 7-14: hornblende-actinolite-bearing amphibolites; and 15-20: hornblendebearing amphibolites.

Abbreviations used: Tremol.: Tremolite; Hornbl.: Hornblende; Actin.: Actinolite; Plag.: Plagioclase, Opaques: Ilmenite, magnetite and $\mathrm{Cu}-\mathrm{Fe}$ sulphides.

Analyst: Dr R Dhana Raju, Petrology Laboratory, AMD Hq., Hyderabad 500016.

An-content and the presence of microcline in the smaller bodies of hornblende-bearing amphibolites indicate that they are more of alkaline than the larger bodies of tremolite-bearing and hornblendeactinolite-bearing amphibolites.

\section{Petrochemistry}

\subsection{Results and petrochemical features}

Chemical analyses of 20 samples of amphibolites, in terms of their major and minor oxides (table 2), CIPW norms (table 3), Niggli values (table 4) and trace elements, including REE for two samples (table 5), are presented.

An examination of the petrochemical data reveals the following main chemical features.

\subsubsection{Classification of amphibolites}

From the analyses of 20 amphibolites (table 2), three groups can be identified, based on their $\mathrm{MgO}$ content. Thus (i) the first six samples (at sl. nos. 1-6) represent high-Mg type with an $\mathrm{MgO}$ content ranging from 9.38 to 15.95 wt.\%, with an average of 13.64 wt.\%; (ii) the samples at sl. nos. 7-14 represent intermediate- $\mathrm{Mg}$ type with an $\mathrm{MgO}$ content ranging from 7.30 to 10.56 wt.\%, with an average of 8.30 wt.\%; and (iii) the samples at sl. nos. 15-20 represent relatively low-Mg type with an $\mathrm{MgO}$ content varying from 4.36 to 7.05 wt.\% with an average of $5.85 \mathrm{wt} . \%$. This classification of amphibolites into high-, intermediate- and low- $\mathrm{Mg}$ types agrees well with their field and petrographic data in that the high-Mg type corresponds to the tremolite-bearing amphibolites, intermediate- $\mathrm{Mg}$ type to hornblende-actinolite-bearing amphibolites and low-Mg type agrees with the hornblendebearing amphibolites.

\subsubsection{Major and minor oxide patterns}

The above Mg-based classification of the amphibolites is corroborated by their other important constituents such as $\mathrm{CaO}, \mathrm{Al}_{2} \mathrm{O}_{3}$ and to some extent $\mathrm{TiO}_{2}$. Thus, the high-Mg type containing tremolite is characterised by low $\mathrm{CaO}(5.47-7.29$ wt.\%, with an average of 6.20 wt.\%), low $\mathrm{Al}_{2} \mathrm{O}_{3}$ (8.50-13.75 wt.\% with an average of 10.61 wt.\%) 


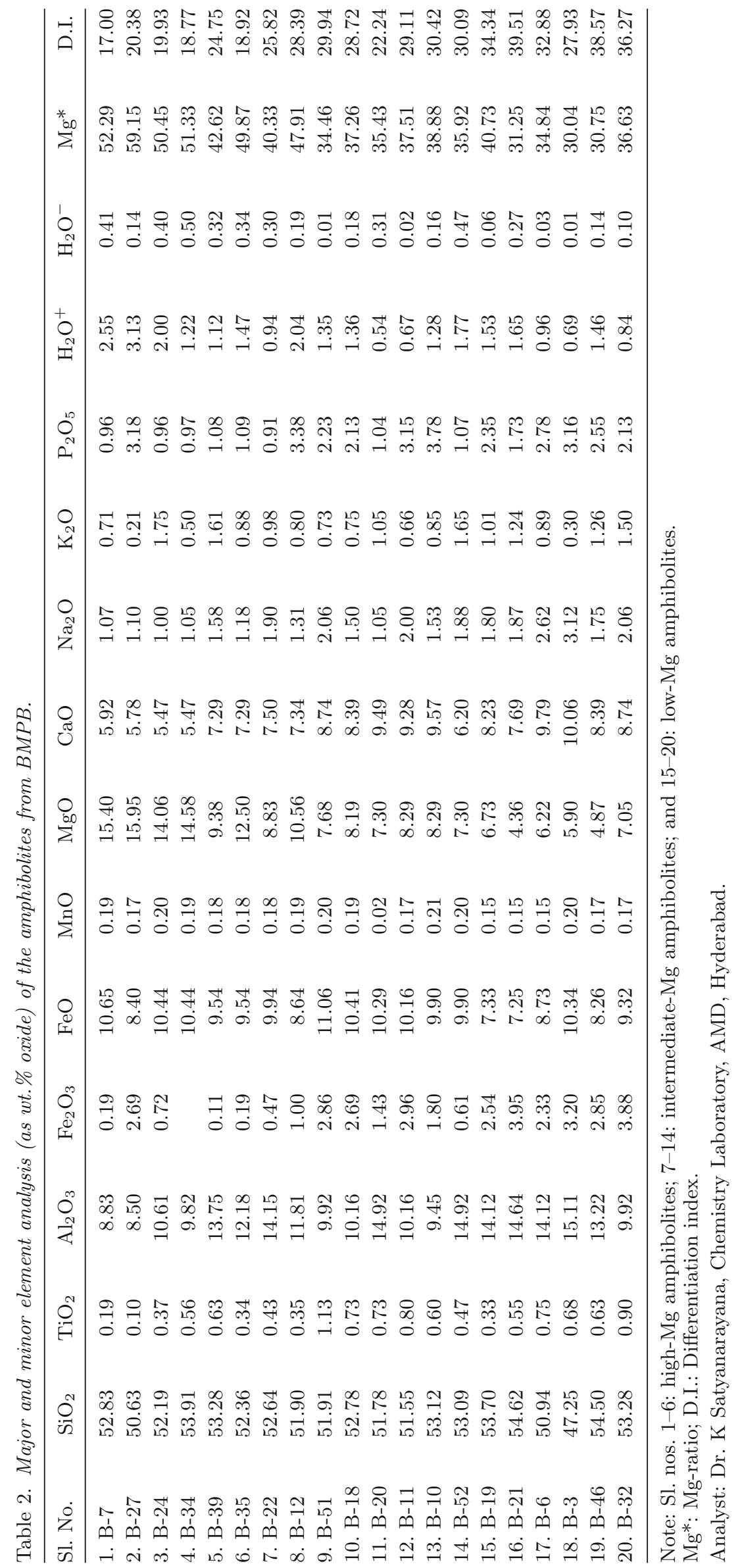


Table 3. CIPW norms of the amphibolites from BMPB.

\begin{tabular}{|c|c|c|c|c|c|c|c|c|c|c|c|}
\hline Sl. No. & $\mathrm{qz}$ & or & $a b$ & an & $\mathrm{c}$ & di & en & fs & $\mathrm{mt}$ & il & ap \\
\hline 1. B-7 & 4.2 & 3.9 & 8.9 & 17.0 & - & 5.2 & 36.0 & 18.2 & 0.2 & 0.3 & 2.0 \\
\hline 2. B-27 & 9.8 & 1.1 & 9.4 & 8.3 & 3.6 & - & 39.9 & 13.3 & 3.9 & 0.2 & 7.7 \\
\hline 3. B-24 & 1.5 & 10.0 & 8.4 & 19.5 & - & 1.6 & 34.6 & 18.5 & - & 0.8 & 2.0 \\
\hline 4. B-34 & 7.1 & 2.8 & 8.9 & 20.6 & - & - & 36.4 & 18.1 & 0.7 & 1.1 & 2.3 \\
\hline 5. B-39 & 5.0 & 6.7 & 13.1 & 27.2 & - & 5.7 & 21.8 & 15.6 & - & 1.2 & 2.3 \\
\hline 6. B-35 & 4.0 & 5.0 & 10.0 & 25.3 & - & 3.7 & 30.1 & 16.4 & 0.2 & 0.6 & 2.3 \\
\hline 7. B-22 & 4.0 & 5.6 & 16.2 & 27.2 & - & 3.7 & 21.0 & 16.6 & 0.7 & 0.8 & 2.0 \\
\hline 8. B-12 & 12.9 & 4.5 & 11.0 & 14.5 & 3.6 & - & 26.4 & 14.8 & 1.4 & 0.9 & 8.1 \\
\hline 9. B-51 & 8.8 & 3.9 & 17.3 & 15.8 & - & 11.2 & 16.2 & 13.9 & 4.2 & 2.1 & 5.0 \\
\hline 10. B-18 & 11.7 & 4.5 & 12.6 & 18.9 & - & 7.3 & 18.5 & 14.3 & 4.0 & 1.4 & 5.0 \\
\hline 11. B-20 & 7.7 & 6.1 & 8.4 & 33.1 & - & 6.2 & 16.6 & 15.1 & 2.1 & 1.4 & 2.4 \\
\hline 12. B-11 & 8.5 & 3.9 & 16.8 & 16.7 & - & 8.5 & 18.2 & 13.3 & 4.2 & 1.3 & 7.4 \\
\hline 13. B-10 & 12.8 & 5.0 & 12.6 & 16.4 & - & 5.9 & 19.1 & 14.8 & 2.6 & 1.2 & 8.7 \\
\hline 14. B-52 & 4.9 & 9.5 & 15.7 & 27.5 & - & 1.2 & 17.9 & 17.7 & - & 0.8 & 2.4 \\
\hline 15. B-19 & 13.0 & 6.1 & 15.2 & 26.1 & 0.4 & - & 16.8 & 11.0 & 3.7 & 0.6 & 5.4 \\
\hline 16. B-21 & 16.6 & 7.2 & 15.7 & 27.2 & 0.2 & - & 10.9 & 9.4 & 5.8 & 1.1 & 4.0 \\
\hline 17. B-6 & 5.9 & 5.0 & 22.0 & 23.9 & - & 6.6 & 13.7 & 11.4 & 3.2 & 1.4 & 6.4 \\
\hline 18. B-3 & 0.1 & 1.7 & 26.2 & 26.4 & - & 2.8 & 11.4 & 18.5 & 4.6 & 1.2 & 7.4 \\
\hline 19. B-46 & 16.7 & 7.2 & 14.7 & 24.5 & - & 0.4 & 11.5 & 11.8 & 4.2 & 1.2 & 6.1 \\
\hline 20. B-32 & 10.1 & 8.9 & 17.3 & 13.3 & - & 13.1 & 13.8 & 10.0 & 5.6 & 1.7 & 5.0 \\
\hline
\end{tabular}

Note: Sl. nos. 1-6: high-Mg amphibolites; 7-14: intermediate-Mg amphibolites; and 15-20: low-Mg amphibolites.

Table 4. Niggli values for the amphibolites of BMPB.

\begin{tabular}{|c|c|c|c|c|c|c|c|c|c|c|}
\hline Sl. No. & $q$ & al & $\mathrm{fm}$ & $\mathrm{c}$ & alk & si & $\mathrm{ti}$ & $\mathrm{p}$ & $\mathrm{k}$ & $\mathrm{mg}$ \\
\hline 1. B-7 & 10.0 & 12.0 & 71.0 & 14.0 & 3.0 & 122.0 & 0.33 & 0.90 & 0.30 & 0.71 \\
\hline 2. B-27 & -1.0 & 11.0 & 72.0 & 14.0 & 3.0 & 111.0 & 0.17 & 2.96 & 0.11 & 0.72 \\
\hline 3. B-24 & -3.0 & 14.0 & 68.0 & 13.0 & 5.0 & 117.0 & 0.62 & 0.92 & 0.54 & 0.69 \\
\hline 4. B-34 & 12.0 & 13.0 & 71.0 & 13.0 & 3.0 & 126.0 & 0.95 & 0.93 & 0.24 & 0.70 \\
\hline 5. B-39 & 10.0 & 20.0 & 55.0 & 19.0 & 6.0 & 134.0 & 1.16 & 1.06 & 0.31 & 0.63 \\
\hline 6. B-35 & 6.0 & 16.0 & 62.0 & 18.0 & 4.0 & 122.0 & 0.59 & 1.06 & 0.33 & 0.69 \\
\hline 7. B-22 & 7.0 & 20.0 & 54.0 & 20.0 & 6.0 & 131.0 & 0.79 & 0.94 & 0.25 & 0.60 \\
\hline 8. B-12 & 14.0 & 17.0 & 59.0 & 20.0 & 4.0 & 130.0 & 0.66 & 3.57 & 0.29 & 0.67 \\
\hline 9. B-51 & 3.0 & 14.0 & 57.0 & 23.0 & 6.0 & 127.0 & 2.08 & 2.32 & 0.19 & 0.50 \\
\hline 10. B-18 & 13.0 & 15.0 & 58.0 & 22.0 & 5.0 & 133.0 & 1.37 & 2.25 & 0.25 & 0.53 \\
\hline 11. B-20 & 11.0 & 21.0 & 50.0 & 25.0 & 4.0 & 127.0 & 1.33 & 1.06 & 0.40 & 0.53 \\
\hline 12. B-11 & 0.0 & 14.0 & 56.0 & 24.0 & 6.0 & 124.0 & 1.45 & 3.21 & 0.18 & 0.53 \\
\hline 13. B-10 & 13.0 & 14.0 & 55.0 & 26.0 & 5.0 & 133.0 & 1.13 & 4.01 & 0.27 & 0.56 \\
\hline 14. B-52 & 10.0 & 23.0 & 52.0 & 17.0 & 8.0 & 142.0 & 0.93 & 1.18 & 0.37 & 0.55 \\
\hline 15. B-19 & 14.0 & 22.0 & 48.0 & 23.0 & 7.0 & 142.0 & 0.65 & 2.64 & 0.27 & 0.55 \\
\hline 16. B-21 & 27.0 & 25.0 & 45.0 & 23.0 & 7.0 & 155.0 & 1.18 & 2.09 & 0.30 & 0.41 \\
\hline 17. B-6 & -6.0 & 20.0 & 46.0 & 26.0 & 8.0 & 126.0 & 1.40 & 2.92 & 0.18 & 0.50 \\
\hline 18. B-3 & -18.0 & 21.0 & 47.0 & 25.0 & 7.0 & 110.0 & 1.19 & 3.11 & 0.06 & 0.44 \\
\hline 19. B-46 & 24.0 & 22.0 & 46.0 & 25.0 & 7.0 & 12.0 & 1.33 & 3.03 & 0.32 & 0.44 \\
\hline 20. B-32 & 7.0 & 15.0 & 54.0 & 24.0 & 7.0 & 135.0 & 1.72 & 2.28 & 0.33 & 0.49 \\
\hline
\end{tabular}

Note. Sl. nos. 1-6: high-Mg amphibolites; 7-14: intermediate-Mg amphibolites; and 15-20: low-Mg amphibolites.

and low $\mathrm{TiO}_{2}(0.10-0.63$ wt. $\%$ with an average of $0.36 \%)$. In contrast, the low-Mg type having hornblende and plagioclase as its major constituents is marked by high $\mathrm{CaO}(7.69-10.06$ wt.\% with an average of 8.82 wt.\%), high $\mathrm{Al}_{2} \mathrm{O}_{3}$ (9.92-15.11 wt.\% with an average of 13.52 wt.\%) and relatively high $\mathrm{TiO}_{2}(0.33-0.90$ wt.\% with an average of 0.64 wt.\%). Compared to the above two types, 
Table 5. Trace element contents, including REE for two samples, (in ppm) of the amphibolites of BMPB.

\begin{tabular}{|c|c|c|c|c|c|c|c|c|c|c|c|c|}
\hline Sl. No. & $\mathrm{Rb}$ & $\mathrm{Sr}$ & $\mathrm{Ba}$ & $\mathrm{Y}$ & $\mathrm{Zr}$ & $\mathrm{Nb}$ & $\mathrm{Zn}$ & V & $\mathrm{Cr}$ & Co & $\mathrm{Ni}$ & $\mathrm{Pb}$ \\
\hline 1. B-7 & 215 & 61 & 39 & 68 & 74 & 19 & 115 & 143 & 1313 & 58 & 347 & 21 \\
\hline 2. B-27 & 27 & 46 & 132 & 15 & 56 & 13 & 95 & 129 & 1731 & 68 & 379 & 20 \\
\hline 3. B-24 & 136 & 31 & 538 & 44 & 74 & 44 & 113 & 145 & 1120 & 63 & 295 & 13 \\
\hline 4. B-34 & 43 & 89 & 15 & 23 & 67 & 13 & 94 & 146 & 1329 & 59 & 339 & 15 \\
\hline 5. B-39 & 79 & 99 & 189 & 36 & 81 & 17 & 86 & 147 & 529 & 50 & 219 & 18 \\
\hline 6. B-35 & 87 & 92 & 222 & 36 & 67 & 18 & 83 & 145 & 999 & 54 & 285 & 16 \\
\hline 7. B-22 & 67 & 117 & 271 & 35 & 92 & 15 & 102 & 161 & 550 & 50 & 230 & 20 \\
\hline 8. B-12 & 54 & 103 & 102 & 39 & 73 & 3 & 77 & 174 & 997 & 50 & 249 & 6 \\
\hline 9. B-51 & 20 & 84 & 187 & 26 & 108 & 9 & 89 & 325 & 580 & 58 & 218 & 13 \\
\hline 10. B-18 & 36 & 131 & 166 & 24 & 143 & 15 & 82 & 259 & 581 & 54 & 222 & 3 \\
\hline 11. B-20 & 526 & 215 & 109 & 40 & 99 & 18 & 84 & 168 & 253 & 49 & 198 & 17 \\
\hline 12. B-11 & 43 & 108 & 99 & 34 & 142 & 6 & 80 & 235 & 780 & 52 & 250 & 10 \\
\hline 13. B-10 & 45 & 11 & 184 & 29 & 137 & 19 & 91 & 204 & 413 & 68 & 197 & 25 \\
\hline 14. B-52 & 233 & 92 & 87 & 75 & 99 & 18 & 90 & 180 & 301 & 34 & 174 & 20 \\
\hline 15. B-19 & 63 & 75 & 204 & 35 & 122 & 13 & 69 & 242 & 313 & 42 & 173 & 13 \\
\hline 16. B-21 & 59 & 97 & 206 & 37 & 147 & 16 & 103 & 152 & 81 & 35 & 135 & 16 \\
\hline 17. B-6 & 35 & 173 & 180 & 18 & 112 & 8 & 82 & 171 & 320 & 32 & 171 & 12 \\
\hline 18. B-3 & 16 & 106 & 133 & 20 & 86 & 3 & 87 & 266 & 334 & 36 & 153 & 34 \\
\hline 19. B-46 & 54 & 104 & 283 & 32 & 139 & 11 & 79 & 210 & 120 & 23 & 143 & 24 \\
\hline 20. B-32 & 46 & 136 & 392 & 31 & 173 & 22 & 121 & 234 & 394 & 32 & 181 & 100 \\
\hline Sl. No. & $\mathrm{La}$ & $\mathrm{Ce}$ & $\mathrm{Sm}$ & $\mathrm{Eu}$ & $\mathrm{Tb}$ & $\mathrm{Yb}$ & $\mathrm{Lu}$ & Total & $(\mathrm{Ce} / \mathrm{Yb})_{\mathrm{cn}}$ & \multicolumn{3}{|c|}{$\mathrm{Eu} / \mathrm{Eu}^{*}$} \\
\hline B-22 & 17 & 28 & 2.9 & 0.7 & 0.2 & 1.7 & 0.25 & 50.87 & 3.87 & \multicolumn{3}{|l|}{1.0} \\
\hline B-19 & 14 & 24 & 3.7 & 0.8 & 0.4 & 2.0 & 0.3 & 45.2 & 2.89 & \multicolumn{3}{|c|}{0.68} \\
\hline
\end{tabular}

Note. Sl. nos. 1-6: high-Mg amphibolites; 7-14: intermediate-Mg amphibolites; and 15-20: low-Mg amphibolites.

Analyst: Dr. S Viswanathan, WDXRFS, AMD, Hyderabad.

B-22: Intermediate-Mg amphibolite; B-19: low-Mg amphibolite.

Analysts: Sher Singh Gurna and N. Satyanarayana, INAA Laboratory, AMD, Hyderabad.

the intermediate- $\mathrm{Mg}$ type, containing hornblende and actinolite, has patterns of $\mathrm{CaO}$ and $\mathrm{Al}_{2} \mathrm{O}_{3}$ of medium contents.

\subsubsection{Critical trace element patterns}

The Mg-based classification of the amphibolites is also corroborated by critical trace element contents (table 5) such as $\mathrm{Cr}, \mathrm{Ni}, \mathrm{Co}$ and $\mathrm{Zr}$. Thus, the high-Mg type is characterised by high $\mathrm{Cr}$ (529$1731 \mathrm{ppm}$, average $1170 \mathrm{ppm})$, Ni (219-379 ppm, average $311 \mathrm{ppm})$ and Co (50-68 ppm, average 59 $\mathrm{ppm})$, and low $\mathrm{Zr}$ (56-81 ppm, average $70 \mathrm{ppm})$. In contrast, the low-Mg type is marked by low Cr (81-394 ppm, average 260 ppm), Ni (135-181 ppm, average $159 \mathrm{ppm})$ and Co (23-42 ppm, average $33 \mathrm{ppm}$ ), and high $\mathrm{Zr}$ (86-173 ppm, average $130 \mathrm{ppm})$. The intermediate- $\mathrm{Mg}$ type is having patterns in between the above two contrasting patterns.

\subsubsection{CIPW norm patterns}

In respect of CIPW norms (table 3), the high-Mg-type amphibolites are characterised by high normative enstatite (21.8-39.9, average 33.1) and ferrosilite (13.3-18.5, average 16.7), and low normative diopside (0.0-5.7, average 2.7$)$, ilmenite (0.2-1.2, average 0.7$)$, magnetite $(0.0-3.9$, average $0.84)$ and apatite $(2.0-7.7$, average 3.1$)$, whereas in the case of the low-Mg type it is vice versa, with the intermediate-Mg type having in-between values. Furthermore, the high-Mg type is marked by a higher value for normative an/ab ratio (0.88-2.5, average 2.0) in contrast to the lower value (0.771.7, average 1.3) for the low-Mg-type amphibolites.

\subsubsection{Discriminatory plots}

When the analysed amphibolites are plotted in relevant bi-linear diagrams with Niggli's mg as the abscissa against Niggli's ti (figure 2a) and alk 

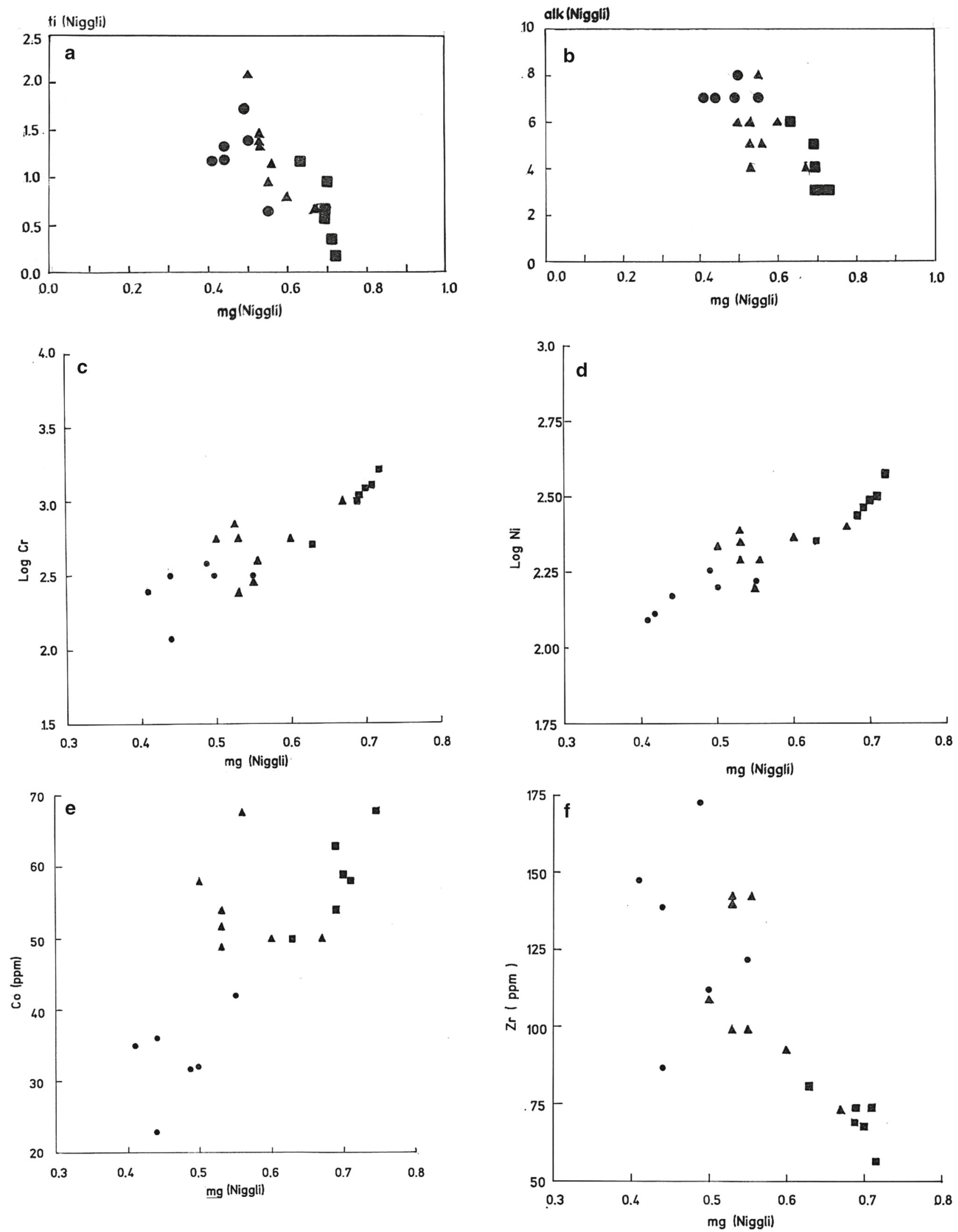

Figure 2. Bi-linear plots of Niggli's mg vs. Niggli's ti (a) and Niggli's alk (b); Niggli's mg vs. log Cr (c), log Ni (d), Co (e) and $\mathrm{Zr}$ (f) (after Leake 1964). Symbols used: squares - high-Mg/tremolite-bearing amphibolites; triangles: intermediate$\mathrm{Mg}$ /hornblende-actinolite-bearing amphibolites; and circles: low-Mg/hornblende-bearing amphibolites. 


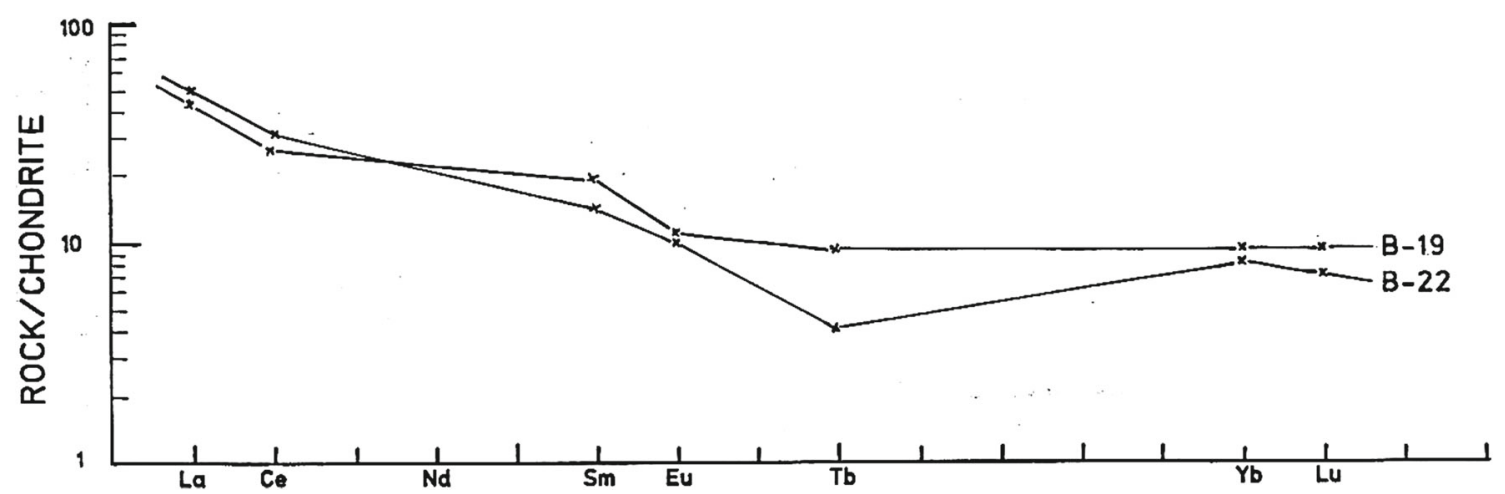

Figure 3. Chondrite-normalised REE plot. B-22: intermediate-Mg amphibolite and B-19: low-Mg amphibolite (chondrite values after Nakamura 1974).

(figure 2b), and $\mathrm{Cr}$ (figure 2c), Ni (figure 2d), Co (figure 2e) and $\mathrm{Zr}$ (figure 2f) as ordinates (Niggli values in table 4 ), it is clearly seen in all these plots that the three types of amphibolites are clearly demarcated. Furthermore, in these plots a clear trend - either negative or positive, depending upon the geochemical relationship of the elements plotted on the ordinate against Niggli's mg - is seen.

\subsubsection{Effect of intrusive pegmatite}

The effect of intrusion of pegmatites into the amphibolites is reflected in the petrochemistry of the latter, particularly with respect to their $\mathrm{K}$ and related trace elements. Thus, the sample nos. B-7, B-24, B-39, B-20 and B-52, which are close to the pegmatite, the effect of pegmatitic intrusion is demonstrated in their relatively higher contents of $\mathrm{K}_{2} \mathrm{O}$ (0.71-1.75 wt.\%, table 2) and $\mathrm{Rb}$ (79-526 ppm, table 5), and to some extent $\mathrm{Ba}$, highest in sample no. B-24 with 538 ppm (table 5). It is also interesting to note that the high- and intermediate-Mg amphibolites (samples at sl. nos. $1-14$ in table 2) are having $\mathrm{SiO}_{2}$ value varying from 50.63 to 53.91 wt.\%, which is certainly higher than the one normally expected for an $\mathrm{MgO}$ content of $15.95-7.30$ wt.\%. This relatively higher $\mathrm{SiO}_{2}$ content could also be ascribed to the pegmatites that are intrusive into the amphibolites.

\subsubsection{REE patterns}

Using the REE data on two samples, one each of intermediate-Mg-type amphibolites (sample no. B-22) and low-Mg-type amphibolites (sample no. B-19) (table 5), their chondrite-normalised patterns are shown in figure 3 . From these data, it is observed that there is not much difference in the total REE and LREE contents of these two types of amphibolites. However, the intermediate-Mg-type amphibolite (B-22) is marked by relatively higher $(\mathrm{Ce} / \mathrm{Yb})_{\text {cn }}$ with no Eu-anomaly $\left(\mathrm{Eu} / \mathrm{Eu}^{*}=1.0\right)$, whereas the low-Mg-type amphibolite (B-19) is characterised by relatively lower $(\mathrm{Ce} / \mathrm{Yb})_{\mathrm{cn}}$ and small negative Eu-anomaly $\left(\mathrm{Eu} / \mathrm{Eu}^{*}=0.68\right)$ (figure 3).

\section{Discussion}

Data and information on the field setting, petrography and petrochemistry of the amphibolites in the area under study, presented heretofore, are critically examined in this section to arrive at their following four important aspects, viz., (i) type of the amphibolites - ortho or para; (ii) chemical nature of their precursor rock(s); (iii) petrogenetic implications; and (iv) bearing of the amphibolites on the pegmatitic RM mineralisation in the area.

\subsection{Type of amphibolites}

As per the field setting in the area under study, the three types of amphibolites, viz., high-Mg type with major tremolite, intermediate- $\mathrm{Mg}$ type with hornblende and actinolite, and low-Mg type with hornblende, are all essentially massive and were emplaced as sills, with sharp contacts, into their host, low-grade Abukuma-type meta-sedimentary rocks. Petrographically, the three types of amphibolites contain more or less equal amounts of amphiboles and twinned (on complex laws) plagioclase as major phases, with minor to accessory quartz, zoisite, chlorite, epidote, wedge-shaped crystals and clusters of sphene, columnar and clusters of radiating needles of apatite, and opaque minerals that comprise mostly ilmenite and 


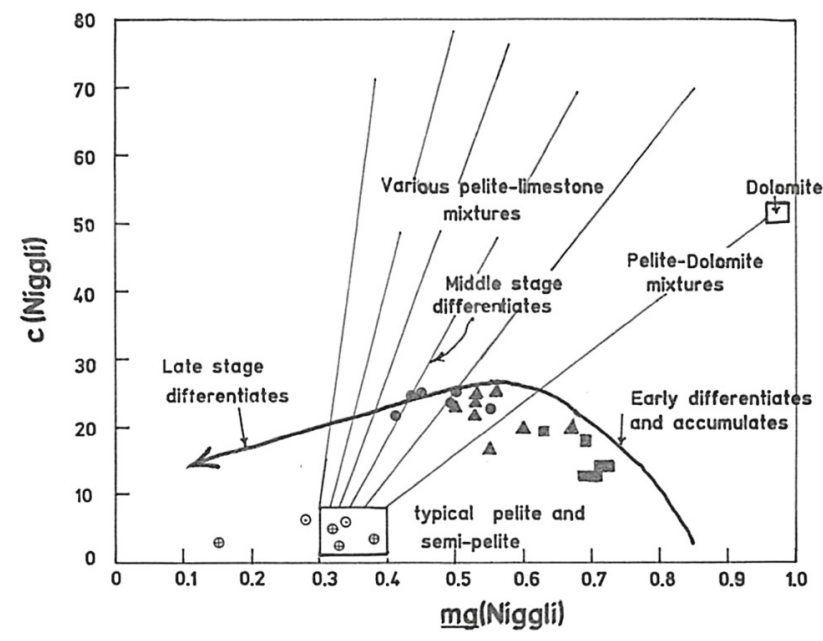

Figure 4. Bi-linear plot of Niggli's mg vs. Niggli's c. Trend line of the Karroo dolerites is shown with an arrow (after Leake 1964). Symbols as in figure 2.

magnetite (table 1). Diopside, a characteristic mineral of para-amphibolites, and almandine that is generally present in the ortho-type are conspicuously absent in these amphibolites, with the latter may be due to low-pressure and low-temperature Abukuma-type metamorphism in the area (Ramesh Babu and Dhana Raju 2018), in which almandine is absent. Petrochemically, the three types of amphibolites are characterised by (a) moderate to very high contents of $\mathrm{Cr}$ (81-1731 ppm) and $\mathrm{Ni}(135$ $379 \mathrm{ppm}$ ) (table 5) and lower values of Niggli's $\mathrm{k}$ (0.06-0.33) (table 4); (b) in Niggli's mg vs. c plot (figure 4) (after Leake 1964), the three types of amphibolites define a trend (from Niggli's mg of 0.7 to 0.4 ), which is more or less similar to that of Karoo dolerites (Walker and Poldervaart 1949) with the high-Mg tremolite-bearing amphibolites plot such as those of early differentiates and accumulates, whereas the intermediate- and low- $\mathrm{Mg}$ type plots in the field of middle stage differentiates, with none in the fields of either dolomite, pelite-dolomite or pelite-limestone mixtures; (c) in Niggli's $100 \mathrm{mg}-\mathrm{c}-$ (al-alk) plot (figure 5), the three types of amphibolites define a trend similar to that of the Karoo dolerites; and (d) in plots involving Niggli's mg vs. ti, alk and critical trace elements such as $\mathrm{Cr}, \mathrm{Ni}, \mathrm{Co}, \mathrm{Zr}$, (figure $2 \mathrm{a}-\mathrm{f}$ ), all the three types of amphibolites define a trend as also in the plot of $\mathrm{Ni}$ vs. Cr (figure 6), with positive trend in the plots with $\mathrm{Cr}, \mathrm{Ni}$ and $\mathrm{Co}$, and negative trend in the plots with ti, alk and Zr. Such regular trend distinctly corresponds to those normally expected in a magmatic differentiation sequence and almost impossible to expect in amphibolites having sedimentary parentage of

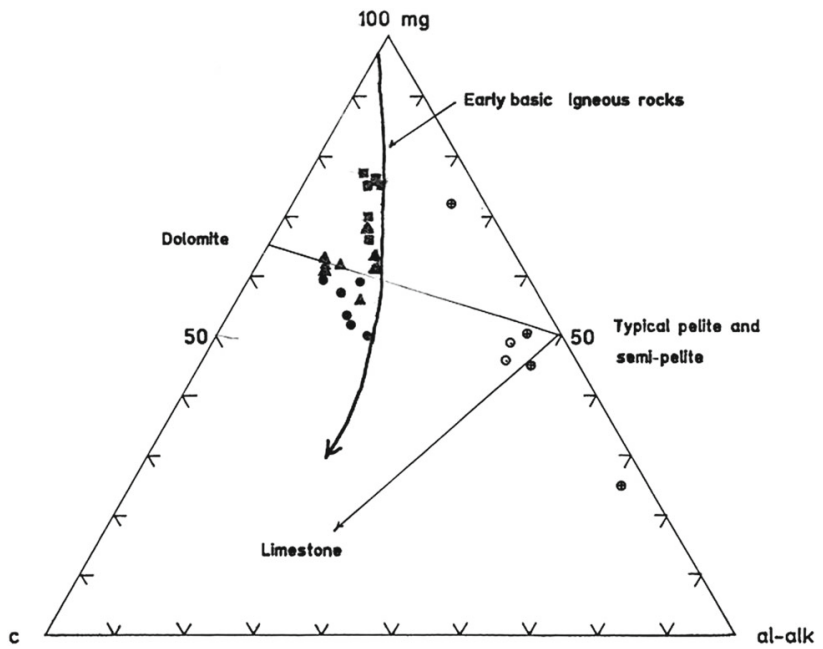

Figure 5. Tri-linear plot of Niggli's $100 \mathrm{mg}-\mathrm{c}-($ al-alk). Trend line of the Karroo dolerites is shown with an arrow (after Leake 1964). Symbols as in figure 2.

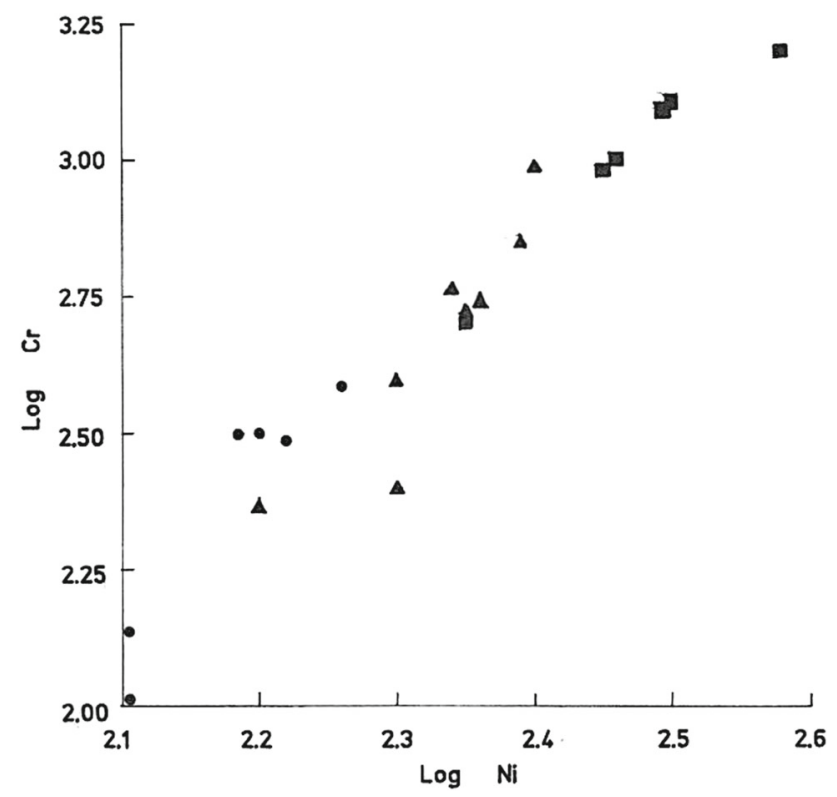

Figure 6. Bi-linear plot of $\log \mathrm{Ni}$ vs. $\log \mathrm{Cr}$ (after Leake 1964). Symbols as in figure 2.

rocks such as pelite, semi-pelite and dolomitelimestone mixtures. Thus, the field, petrographic and petrochemical features cumulatively point out that the amphibolites in the area under study are of ortho-type; in the following section, the nature of their parental magma is discussed.

\subsection{Nature of parental magma}

Prior to using the geochemistry of these orthoamphibolites to probe the nature and type of their parental magma, it is important to assess the effects of alteration on their chemistry. 


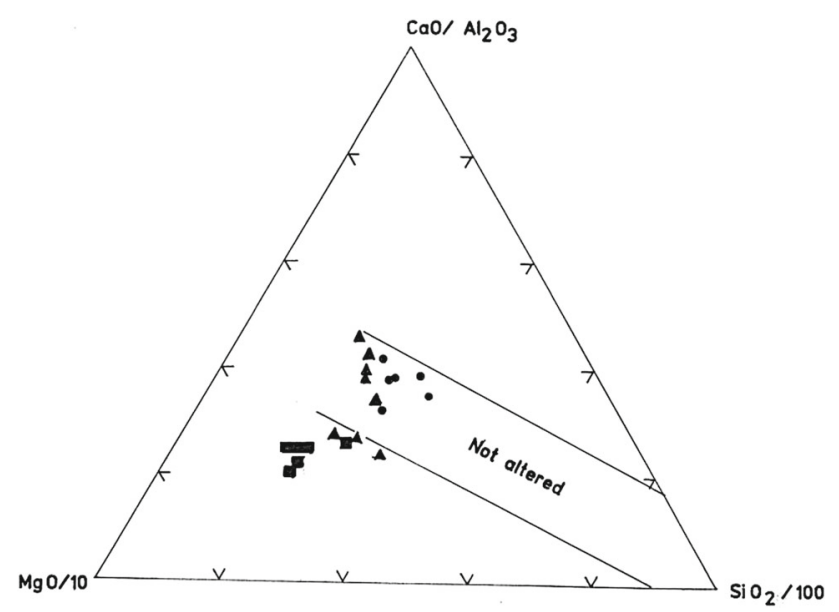

Figure 7. Ternary system of $\mathrm{CaO} / \mathrm{Al}_{2} \mathrm{O}_{3}-\mathrm{MgO} / 10-$ $\mathrm{SiO}_{2} / 100$ to recognise alteration of the samples (after Davies et al. 1978). Symbols as in figure 2.

Petrographically, the important mineralogical alterations noted are chloritisation (Mg-rich chlorite from tremolite and Fe-rich from hornblende) and lesser degree epidotisation of amphiboles, cholritisation and saussuritisation of plagioclase, and formation of sphene from ilmenite and calcic plagioclase. These alterations took place during auto-hydrothermal processes at low temperatures. As these amphibolites are of ortho-type, it may be surmised that their amphiboles are the products derived from the original minerals such as olivine and pyroxene. It is significant to note that neither calcitisation nor serpentinisation is observed in the amphibolites. In order to recognise the extensively altered amphibolites, all the analysed samples were plotted in the ternary system, $\mathrm{CaO} / \mathrm{Al}_{2} \mathrm{O}_{3}-\mathrm{MgO} / 10-\mathrm{SiO}_{2} / 100$ (after Davies et al. 1978; figure 7) in which all the low- $\mathrm{Mg}$ and most of the intermediate-Mg type plot in 'Not altered field'. Most of the high-Mg type and a few of the intermediate-Mg-type amphibolites plot a little outside or in the border zone of this field towards the ' $\mathrm{Mg}$ ' apex; indeed, these amphibolites contain either tremolite or actinolite, pointing to the possible relative enrichment of $\mathrm{Mg}$ during the formation of these amphiboles from their precursor olivine and/or pyroxene. $\mathrm{FeO} / \mathrm{Fe}_{2} \mathrm{O}_{3}$ ratio, an indicator of the state of oxidation, is generally low $(0.02-0.32)$ in the high- and intermediate-Mg-type amphibolites, whereas relatively higher $(0.27-0.54)$ in the low-Mg-type amphibolites. This feature can be comparable with the field setting of these amphibolites, in that high- and intermediate- $\mathrm{Mg}$ types occur at relatively deeper levels as larger bodies, whereas the low-Mg type is confined to higher

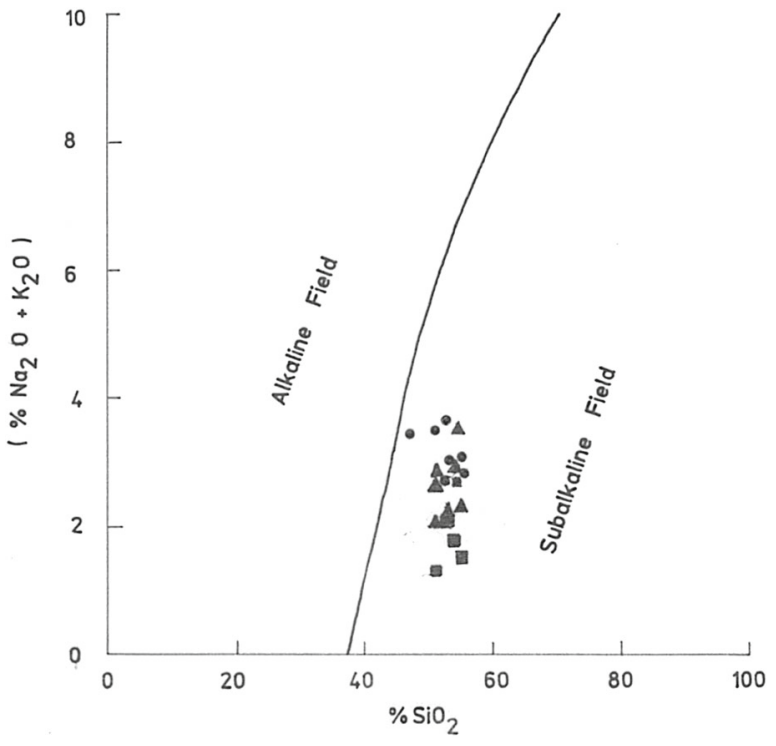

Figure 8. Bi-linear plot of $\% \mathrm{SiO}_{2}$ vs. $\%\left(\mathrm{Na}_{2} \mathrm{O}+\mathrm{K}_{2} \mathrm{O}\right)$ to distinguish alkaline and sub-alkaline volcanic rocks (after Irvine and Baragar 1971). Symbols as in figure 2.

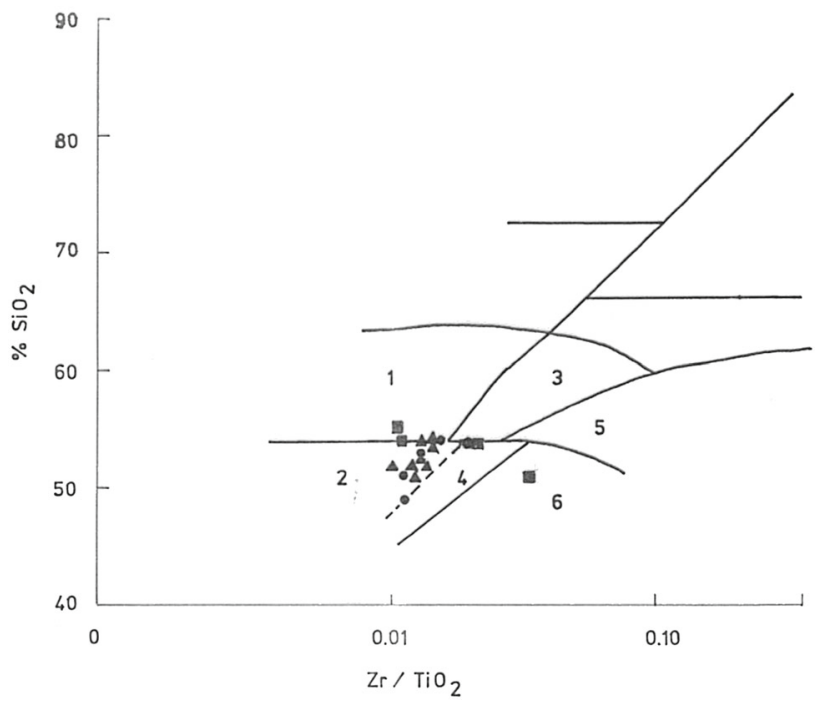

Figure 9. Bi-linear plot of $\mathrm{Zr} / \mathrm{TiO}_{2}$ vs. $\% \mathrm{SiO}_{2}$ for separating 1 - andesites, 2 - sub-alkaline basalts, 3 - trachyandesites, 4 - alkali basalts, 5 - phonolites and 6 - basanite (after Floyd and Winchester 1978). Symbols as in figure 2.

levels as smaller bodies. In the bi-linear diagrams, viz., $\mathrm{SiO}_{2}$ vs. alkalies (figure 8, after; MacDonald and Katsura 1964; Irvine and Baragar 1971) and $\mathrm{Zr} / \mathrm{TiO}_{2}$ vs. $\mathrm{SiO}_{2}$ (figure 9; after Floyd and Winchester 1978), most of the amphibolites plot in the field of 'sub-alkaline basalts'. To find out the true nature of these sub-alkaline rocks (tholeiitic or calc-alkaline), the samples were plotted in the bi-linear diagram of normative plagioclase $v s$. $\mathrm{Al}_{2} \mathrm{O}_{3}$ (figure 10, after Irvine and Baragar 1971), when it is noted that all of them plot in the 


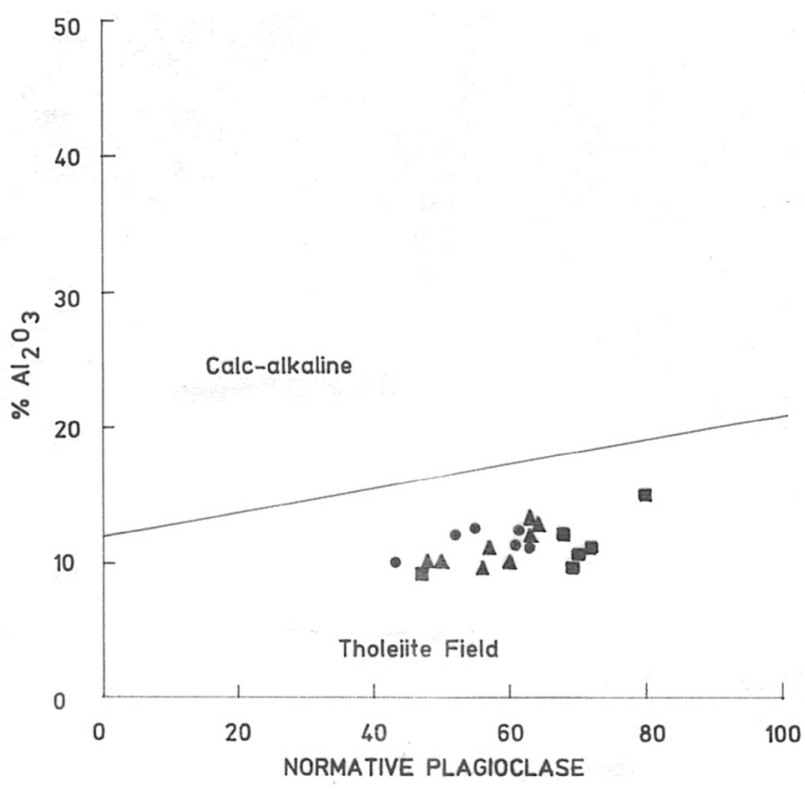

Figure 10. Bi-linear plot of normative plagioclase vs. $\% \mathrm{Al}_{2} \mathrm{O}_{3}$ to distinguish tholeiitic from calc-alkaline rocks (after Irvine and Baragar 1971). Symbols as in figure 2.

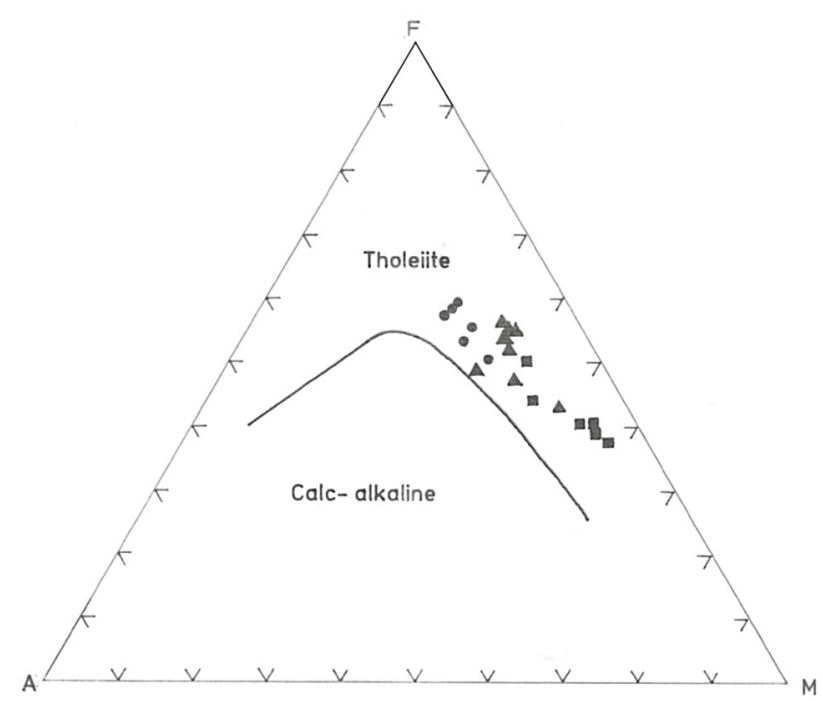

Figure 11. AFM diagram showing the fields of tholeiitic and calc-alkaline basalts (after Irvine and Baragar 1971). Symbols as in figure 2 .

tholeiitic field. This is also corroborated by their plots in the alkalies $\left(\mathrm{Na}_{2} \mathrm{O}+\mathrm{K}_{2} \mathrm{O}\right)-(\mathrm{FeO}+$ $\mathrm{Fe}_{2} \mathrm{O}_{3}$ ) - $\mathrm{MgO}$ (AFM) diagram (figure 11, after Irvine and Baragar 1971) in which all the three types of amphibolites are in the tholeiitic field. Furthermore, in this diagram, all the amphibolites define a clear trend of Fe-enrichment from high-Mg- to low-Mg-type amphibolites. It is thus established that these ortho-amphibolites are sub-alkaline and tholeiitic in nature, with a well-defined Fe-enrichment from the high- $\mathrm{Mg}$ through intermediate-Mg to low-Mg amphibolites. Of the three types of amphibolites, some of the tremolite-bearing ones (sample nos. B-7, B-27, B24 and B-34) are marked by high $\mathrm{MgO}$ content (14-16 wt.\%) and relatively low $\mathrm{TiO}_{2}$ content (0.10.6 wt.\%) (table 2), with high Ni (295-3379 ppm) and $\mathrm{Cr}$ (1120-1731 ppm) (table 5), resembling 'komatiitic basalts'. The absence of characteristic features of komatiites such as field association with ultramafic rocks, petrographic features of spinifex texture with occasional magnesian pigeonite and usually sodic plagioclase, and diagnostic chemical feature of $\mathrm{CaO} / \mathrm{Al}_{2} \mathrm{O}_{3}>0.8-1$ (Arndt and Nesbitt 1982) point to the non-komatiitic nature of the amphibolites under study, in spite of their high $\mathrm{Mg}, \mathrm{Ni}$ and $\mathrm{Cr}$, and low $\mathrm{TiO}_{2}$ contents. Also, the tremolite-bearing amphibolites may be considered as 'cumulates', but the absence of typical cumulate textures such as poikilitic texture (olivine/pyroxene within plagioclase) rules out their being cumulates. In the light of these observations and due to distinct linear trend from high-Mg- to low-Mg-type amphibolites in Niggli's $\mathrm{mg}$ vs. c (figure 4) and AFM plots (figure 11), besides their field occurrence at relatively lower levels compared to low-Mg type, it appears most probably that the high-Mg type could be an early differentiate of the parental tholeiitic magma, possibly quartz tholeiitic magma, indicated by normative quartz (1.5-16.7) (table 3) in all the analysed samples.

\subsection{Petrogenetic implications}

(a) It was shown earlier that the three types of amphibolites belong to early to middle stage differentiates, as indicated in their Niggli's mg vs. c diagram (figure 4), and the observed systematic variation between Niggli's mg and others [negative correlation with Niggli's ti and alk, and $\mathrm{Zr}$ (figure $2 \mathrm{a}, \mathrm{b}$ and $\mathrm{f}$ ) and positive correlation with $\mathrm{Cr}, \mathrm{Ni}$ and $\mathrm{Co}$ (figure $2 \mathrm{c}-\mathrm{e}$ )] points out to the operation of high degree of fractional crystallisation during the petrogenesis of these amphibolites. (b) Plots of amphibolites in $\mathrm{Zr}$ vs. $\mathrm{TiO}_{2}$ (figure 12) indicate distinct directions, which, when compared with theoretical fractionation vectors, the controlling crystallising phases appear to be plagioclaseapatite-olivine-clinopyroxene, which characterise the tholeiitic fractional trends (Pearce and Norry 1979). (c) When the analysed amphibolites are plotted in the covariance diagram of a compatible element, Cr with an incompatible and immobile 


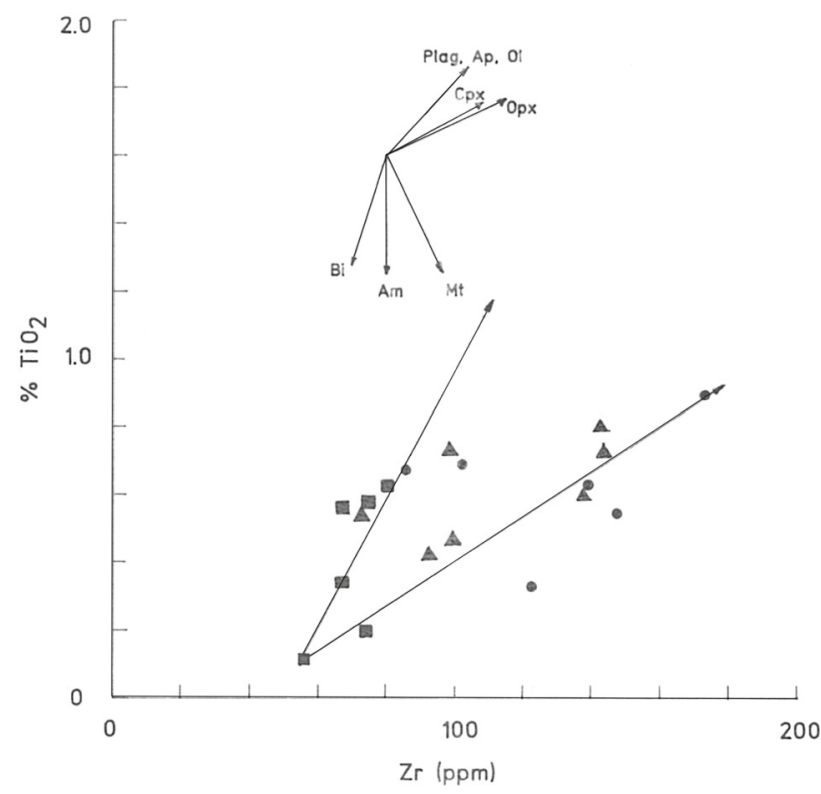

Figure 12. Bi-linear plot of $\mathrm{Zr}$ (ppm) vs. $\% \mathrm{TiO}_{2}$, with fractionation vectors (after Pearce and Norry 1979). Symbols as in figure 2 .

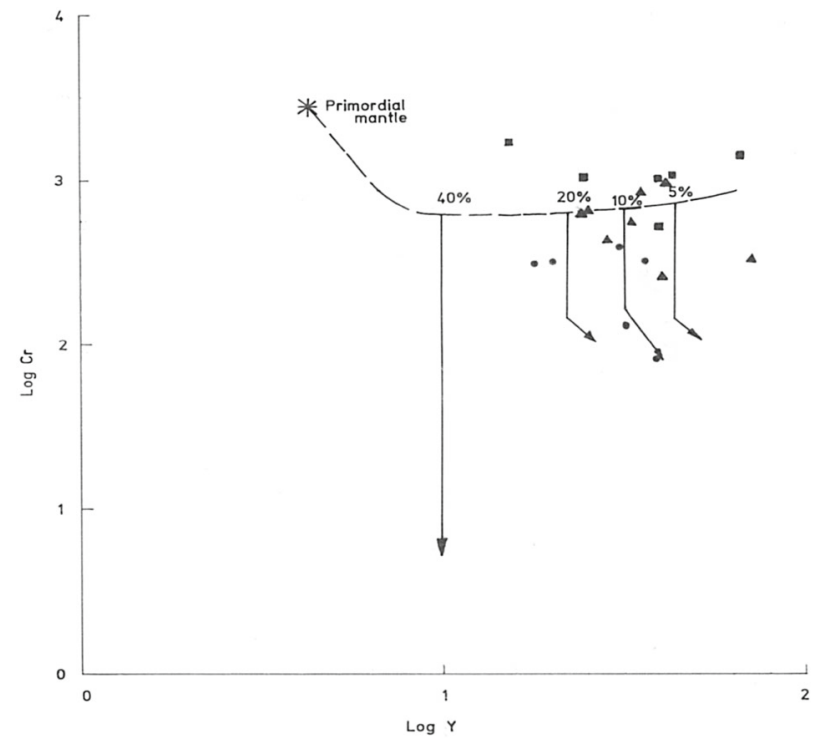

Figure 13. Bi-linear plot of $\log Y$ vs. $\log \mathrm{Cr}$, showing variations within the amphibolites under study and the petrogenetic pathways that connect them to primordial mantle composition. $5 \%, 10 \%, 20 \%$ and $40 \%$ refer to the degree of partial melting of the primordial mantle material (after Pearce 1982). Symbols as in figure 2.

element, $Y$ (figure 13, after Pearce 1982), it is observed that almost all the intermediate- and low-Mg-type amphibolites are showing the important role of fractional crystallisation, corroborating the earlier arrived inference. During fractional crystallisation, trends of these amphibolites are extended to meet the trend of partial melting in this diagram, their intersections indicate $\sim 5-25 \%$ partial melting of the primordial mantle of Wood (1979). It is interesting to note that most of the high-Mg-type amphibolites also fall in this range of partial melting with, however, a little enrichment of Cr than that expected due to partial melting of the primordial mantle. This is probably due to the early differentiated and early separation of high$\mathrm{Mg}$ minerals such as olivine and clinopyroxene from the primordial magma. (d) The observed REE contents, both of LREE and HREE (table 5), and the chondrite-normalised patterns (figure 3) are more or less comparable to those of early Precambrian tholeiites of NE Minnessota (Arth and Hanson 1975). In this, attention is drawn to a very gentle slope of REE pattern from LREE to HREE with a small negative Eu-anomaly for tholeiite formed by $10 \%$ partial melting and no Eu-anomaly for tholeiite formed by $25 \%$ partial melting of peridotite at shallow depths $(<30 \mathrm{~km})$, leaving a residue composed predominantly of olivine and orthopyroxene (refer figure 5b on p. 337 of Arth and Hanson 1975). (e) It appears that the primordial mantle that gave rise to the melts leading ultimately to the formation of amphibolites under study is enriched, and such enrichment is indicated by high content of $\mathrm{P}_{2} \mathrm{O}_{5}$ (0.91-3.78\%, table 2) and $\mathrm{Rb}(16-87 \mathrm{ppm}$, table 5) in samples comparatively not influenced by pegmatite emplacement, since enriched mantle components are mantle reservoirs, enriched in $\mathrm{Rb}, \mathrm{Sm}, \mathrm{U}$ (and $\mathrm{Th}$ ) relative to $\mathrm{Sr}, \mathrm{Nd}$ and $\mathrm{Pb}$, respectively (Condie 1989). (f) Extrapolating the above inferences, namely the parental magma for the study amphibolites is tholeiite, possibly quartz tholeiite, and the partial melting being the order of $5-25 \%$, on depth $(\mathrm{km})$ vs. per cent melting diagram (in figure 7.12 of Condie 1989), it appears that the parental magma should be 'quartz tholeiite' with a depth of $\sim 10-25 \mathrm{~km}$ for production of such a magma. Such relatively shallow depth for the generation of parental magma indicates steeper geothermal gradients. It is interesting to note that such steep geothermal gradient in the area is also supported by the Abukuma-type facies of metamorphism, inferred for the co-existing metasedimentary rocks in the area under study (Ramesh Babu 1993; Ramesh Babu and Dhana Raju 2016).

\subsection{Bearing of amphibolites on the pegmatitic $R M$ mineralisation}

The S-type granite (Ramesh Babu and Dhana Raju 2016) and meta-sedimentary rocks, with the 
exception of quartzite, host only type I and II pegmatites, whereas the important tin- and RMbearing pegmatites of types III, IV and V, along with types I and II, are hosted by amphibolites (Ramesh Babu 1990, 1993). As the pegmatite melt, along with its rare-element and volatile components $\left(\mathrm{F}, \mathrm{Cl}\right.$ and $\mathrm{B}$, along with $\left.\mathrm{H}_{2} \mathrm{O}\right)$ tends to migrate from the parental granite, it is expected that the parent granite is devoid of any mineralised pegmatites, as observed in the case of the Paliam granite in the study area (Ramesh Babu 1990, 1993; Ramesh Babu and Dhana Raju 2016). The meta-sedimentary rocks are relatively more pervasive (with foliation, bedding, etc.) and less competent, as compared to the massive and more competent amphibolites in the area. The amphibolites offer cavities of favourable forms and their non-pervasive nature creates conditions for regular and prolonged consolidation of the pegmatite melt solution along with rare-element-rich volatile components (Vlasov 1956, cited from Solodov 1964) to form well-zoned pegmatites, with the development of replacement units of greiseinisation and albitisation, which are rich in mineralisation of RMs and tin (cf. Lamba and Agarkar 1988). In contrast, the meta-sedimentary rocks, except quartzite, although have favourable locii, due to their pervasive nature, much of the rare-element-rich volatile components of the pegmatite melt solution escape the system into the surrounding rock thereby hindering the formation of well-zoned and highly mineralised pegmatites. This feature is supported by very high contents of $\mathrm{Rb}(1242 \mathrm{ppm})$ and $\mathrm{Nb}(70 \mathrm{ppm})$ in the andalusite schist, collected from near a pegmatite of type II. Apart from the massive and more competent nature of the amphibolites, their highly contrasting chemical nature (basic), as compared to the ultraacidic nature of intrusive pegmatitic melt, might have also helped in arresting the latter leading to mineralised pegmatites that are in contact with the amphibolites, as is the case in the area under study.

\section{Conclusions}

Amphibolites and meta-sedimentary rocks, belonging to the Archaean Bengpal Group having a regional metamorphic event around $2530 \pm 89 \mathrm{Ma}$, were intruded by mineralised and hitherto partly exploited RM (Nb-Ta, Be and Li)- and Sn-bearings granite pegmatites in the BMPB in the SE part of the Bastar craton in the states of Chhattisgarh and Odisha. Based upon the field setting and petrography, these amphibolites are classified as (i) tremolite-, (ii) hornblende-actinolite- and (iii) hornblende-bearing amphibolites, the petrochemistry of which corresponds, respectively, to high$\mathrm{Mg}$, intermediate- $\mathrm{Mg}$ and low- $\mathrm{Mg}$ amphibolites. The field, petrography and major-minor-trace elements petrochemistry, including REEs, and petrochemical patterns cumulatively point out that these amphibolites are ortho and sub-alkaline in nature, with tholeiitic, and possibly quartz tholeiitic magmatic affinity, and formed due to more of fractional crystallisation and less of $5-25 \%$ partial melting of an enriched primordial mantle magma (enriched mid-oceanic ridge basalt - E-MORB), emplaced at a deduced shallow depth of 10-25 $\mathrm{km}$, with the main controlling phases being olivine, plagioclase, clinopyroxene and apatite; they show similarity to the Precambrian tholeiites of Minnesota, USA.

\section{Acknowledgements}

This paper forms a part of the $\mathrm{PhD}$ thesis of PVRB, under the supervision of RDR. The authors express their sincere thanks to their former colleagues (i) in the Atomic Minerals Directorate (AMD) for Exploration and Research, Department of Atomic Energy, Government of India for their support in the field during the course of fieldwork and (ii) in different laboratories of AMD Headquarters, Hyderabad, for analytical data. Two anonymous reviewers of the journal are sincerely thanked for their comments and suggestions, which helped in improving the quality of the paper.

\section{References}

Acharya B C, Das S K, Sahoo R K, Patnaik B C and Das N K 1989 Mineralogy of tin ores from Koraput District, Orissa; J. Geol. Soc. India 34(4) 405-412.

Arndt N T and Nesbitt E G 1982 What is a Komatiite?; In: Komatiites (eds) Arndt N T and Nesbitt E G, George Allen and Unwin, London, 526p.

Arth J G and Hanson G N 1975 Geochemistry and origin of the early Precambrian crust of northeastern Minnesota; Geochim. Cosmochim. Acta 39 325-362.

Bandyopadhyay B K, Bhoskar K G, Ramachandra N M, Roy A, Khader V K, Mohan M, Sreeramachandra Rao K, Ray Barman T, Bishvi P K and Gupta S N 1990 Recent geochronological studies in parts of the Precambrian of central India; Geol. Surv. India, Spec. Publ. 28 199-210.

Bhola K L and Bhatnagar G S 1969 Occurrence of beryl in Madhya Pradesh and adjoining Simdega subdivision of Bihar; Quart. J. Geol. Mining Met. Soc. India XLI(1) $37-44$. 
Chawla A S 1988 A report on the geological evaluation of aeroradiometric data in and around Indravati Basin, M.P., India; Atomic Minerals Division, Hyderabad (Unpublished report).

Condie K C 1989 Plate tectonics and crustal evolution (3rd edn), Pergaman Press, 476p.

Crookshank H 1963 Geology of the Southern Bastar and Jeypore from the Bailadila range to the eastern Ghats; Geol. Surv. India Memoir $\mathbf{8 7}$ 149p.

Davies A, Blackburn W H, Brown W R and Ehmann W D 1978 Trace element geochemistry and origin of Late Precambrian - Early Cambrian Catoctin greenstones of the Applachian mountains; Univ. of California at Davies, California (unpublished).

Deshpande M L 1976 Cassiterite-lepidolite-bearing pegmatites in Bastar dist., M.P.; Indian Miner. 30(1) 67-74.

Floyd P A and Winchester J A 1978 Identification and discrimination of altered and metamorphosed volcanic rocks using immobile elements; Chem. Geol. 21 291-306.

Gurna S S, Satyanarayana N, Dhana Raju R, Selvam A P and Virnave S N 1988 Instrumental neutron activation analysis in the study of rare earth elements and related trace elemental distribution in the Mahadek sandstones from Pdengshakap, Jaintia Hills District, Meghalaya and its bearing on exploration; In: Proceedings of the national symposium on 'Analytical Applications in Earth Sciences', Ind. Soc. Analytical Scientists (ISAS), pp. 2-8 (issued in February 1992).

Irvine T N and Baragar W R A 1971 A guide to the chemical classification of some common volcanic rocks; Can. J. Earth Sci. 8 523-548.

Lamba V J S and Agarkar P S 1988 The tin potential of Precambrian rare-metal bearing pegmatites of Bastar District, M.P., India; Mineral. Deposita 23 218-221.

Lamba V J S and Khanna V K 1981 Characteristic features of tin-bearing rare-metal pegmatites of Konta tahsil, Bastar District, M.P.; Bull. Ind. Geol. Assoc. 14(2) 151-154.

Leake B E 1964 The chemical distinction between ortho- and para-amphibolites; J. Petrol. 5 238-254.

MacDonald G A and Katsura T 1964 Chemical composition of Hawiian lavas; J. Petrol. 5 82-133.

Murthy K S, Jaiswar H P and Jesany R S 1979 Geology in relation to tin mineralisation in Bastar district, M.P. Workshop on 'Mineralisation associated with acid magmatism', Nagpur; Geol. Surv. India, Spec. Publ. 13 61-70.

Nakamura N 1974 REE contents of chondrite; Geochim. Cosmochim. Acta 38 753-773.

Pearce J A 1982 Trace element characteristics of lavas from destructive plate boundaries; In: Andesites (ed.) Thorpe R S, John Wiley and Sons, pp. 525-548.

Pearce J A and Norry M J 1979 Petrogenetic implications of Ti, Zr, Y and Nb variations in volcanic rocks; Contrib. Mineral. Petrol. $6933-47$.

Ramachar T M, Shivananda S R, Dwivedy K K and Jayaram K M V 1979 The rare metal and REE occurrences in south Bastar district, Madhya Pradesh; Presented at the Workshop on 'Mineralisation associated with acid magmatism', Nagpur; Geol. Surv. India, Spec. Publ. 13 104-107.
Ramakrishnan M 1990 Crustal development in southern Bastar, Central India craton; Geol. Surv. India, Spec. Publ. 28 44-66.

Ramaswamy C, Deshpande M L, Murti K S, Jaiswar H P and Jesani R S 1976 Tin-bearing pegmatites of Bastar, M.P.; Geol. Surv. India, Spec. Publ. 3 185-189.

Ramesh Babu P V 1990 Petrology, geochemistry and mineralisation in parts of the Bastar-Koraput Pegmatite Belt, Madhya Pradesh and Orissa, India; PhD Thesis (unpublished), Osmania Univ., Hyderabad, 178p.

Ramesh Babu P V 1993 Tin and rare metal pegmatites of the Bastar-Koraput Pegmatite Belt, Madhya Pradesh and Orissa, India: Characterisation and classification; J. Geol. Soc. India 42(2) 180-190.

Ramesh Babu P V 1999 Rare metal and rare earth pegmatites of central India; In: Special issue on 'Rare metal and rare earth pegmatites of India' (eds) Mahadevan T M and Dhana Raju R, Expl. Res. At. Min. 12 7-52.

Ramesh Babu P V and Dhana Raju R 2016 Granites, parental to the Bastar-Malkangiri tin-rare metal pegmatites in Chhattisgarh and Odisha, India; In: Proceedings volume, 'Hutton India conference', 27 November 2016, Hyderabad, pp. 103-115.

Ramesh Babu P V and Dhana Raju R 2018 Geochemistry and metamorphic history of the meta-sedimentary rocks in the Bastar-Malkangiri pegmatite belt in parts of Chhattisgarh and Odisha, India; J. Appl. Geochem. 20(3) 313-324.

Ramesh Babu P V and Ramachar T M 1983 A note on the newly discovered columbite-tantalite, beryl and cassiterite bearing pegmatites in Katekalyan area, Bastar District, M.P.; Curr. Sci. 52 24-25.

Ramesh Babu P V, Pandey B K and Dhana Raju R 1993 $\mathrm{Rb}-\mathrm{Sr}$ ages on the granite and pegmatitic minerals from Bastar-Koraput pegmatite belt, Madhya Pradesh and Orissa, India; J. Geol. Soc. India 42(1) 33-38.

Reddy C R, Pant D R, Rao B L and Sankar Das M 1975 Neutron activation analysis of 13 minor and trace elements in geological samples; Radioanal. Chem. 33 39-51.

Satyanarayana K 1986 Geochemistry of amphibolites and associated rocks in parts of the Nellore - Gudur pegmatite belt, Andhra Pradesh; Ph.D. Thesis, Osmania Univ., Hyderabad (Unpublished), 264p.

Shapiro L and Brannock W W 1955 Rapid analysis of silicate, carbonate and phosphate rocks; U.S. Geol. Surv. Bull. 144-A.

Solodov N A 1964 The criteria of evaluation of rare-metal granite-pegmatites; 22nd Session, Int. Geol. Cong. India Proc. Vol. of Section 6 on 'Minerals and Genesis of Pegmatites', pp. 193-212.

Viswanathan S 1989 Wavelength-dispersive X-ray fluorescence spectrometry in exploration and research for atomic minerals; Expl. Res. At. Miner. 2 247-268.

Walker F and Poldervaart A 1949 Karroo dolerites of the union of south Africa; Bull. Geol. Soc. Am. 60 591-706.

Wood D A 1979 A variably veined sub-oceanic upper mantle - genetic significance for mid-ocean ridge basalts from geochemical evidence; Geology 7 499-503. 